Perimbangan Keuangan antara Pemerintah Pusat dan Daerah.

Undang-Undang Nomor 32 Tahun 2004, Tentang Pemerintahan Daerah.

Undang-Undang Nomor 33 Tahun 2004, Tentang Perimbangan Keuangan antara Pemerintah Pusat dan Daerah.
Peraturan Pemerintah Nomor 104 Tahun 2000, Tentang Dana Perimbangan.

Peraturan Pemerintah Nomor 105 Tahun 2000, Tentang Pengelolaan dan Pertanggung jawaban Keuangan Daerah.

Peraturan Pemerintah Nomor 55 Tahun 2005 Tentang Dana Perimbangan. 


\title{
PERSEPSI PETANI TERHADAP INOVASI TEKNOLOGI PESTISIDA NABATI LIMBAH TEMBAKAU (Suatu Kasus pada Petani Tembakau di Kabupaten Sumedang)
}

\author{
Pingkan Aditiawati ${ }^{1)}$, Mia Rosmiati ${ }^{2)}$, dan Dadang Sumardi ${ }^{3)}$ \\ ${ }^{1)}$ Bioteknologi Mikroba SITH- ITB, \\ 2) Manajemen Sumberdaya Hayati SITH - ITB \\ 3) Genetika dan Bioteknologi Molekuler SITH - ITB \\ E-mail : pingkan@sith.itb.ac.id
}

\begin{abstract}
Abstrak. Sebagai suatu inovasi, proses adopsi pestisida nabati limbah tembakau membutuhkan suatu proses pemahaman (persepsi) oleh para petani. Suatu inovasi akan diadopsi oleh petani jika mereka mempunyai persepsi yang baik terhadap inovasi tersebut. Oleh karena itu, tujuan penelitian ini akan mengkaji bagaimana persepsi petani terhadap teknologi pestisida nabati limbah tembakau. Penelitian ini dilaksanakan di daerah sentra pengolahan tembakau di Kabupaten Sumedang yaitu di Kecamatan Sukasari dan Tanjungsari. Metode yang digunakan pada penelitian ini adalah metode deskriptif. Penentuan responden dilakukan secara sensus terhadap petani yang mengikuti pelatihan teknologi pestisida nabati limbah tembakau (40 responden). Persepsi petani terhadap inovasi teknologi pestisida nabati limbah tembakau dilihat dari indikator sifat inovasi yaitu relative advantage, compatibility, complexity, triability, dan observability, kemudian diukur dengan menggunakan skala likert. Data tersebut dianalisis dengan menggunakan statistika deskriptif. Hasil penelitian menunjukkan bahwa persepsi petani terhadap inovasi teknologi pestisida nabati limbah tembakau termasuk kriteria positif. Jika petani mempunyai persepsi yang baik diharapkan proses adopsi inovasi pestisida nabati limbah tembakau oleh petani dapat berjalan secara cepat.
\end{abstract}

Kata Kunci : inovasi teknologi, persepsi, pestisida nabati, sifat inovasi

\section{FARMER PERCEPTIONS OF TECHNOLOGY INNOVATION OF BOTANICAL PESTICIDE FROM TOBACCO WASTE}

(A Case on Tobacco Farmers in Sumedang District)

\begin{abstract}
As an innovation, botanical pesticide with active ingredients from tobacco waste product requires a perceptual processes to be adopted by the farmers. An innovation will be adopted by farmers if they have a good perception of the innovation. Therefore, the purpose of this study will examine how perceptions of farmers on botanical pesticide technology from tobacco waste product. This research was conducted in the area of tobacco processing centers in Sumedang. The method used in this research is descriptive method. Determination of respondents conducted a census of all farmers who attended training about botanical pesticide technology with active ingredients from tobacco waste product (40 respondents). Farmer's perception on technological innovation botanical pesticide seen of indicators characteristic of innovation are relative advantage, compatibility, complexity, triability, and observability, then measured using a Likert scale. The data were analyzed using descriptive statistics. The results showed that the perception of farmers towards technological innovation showed positive perception. With a positive perception of the farmer, the adoption of innovation of the botanical pesticide technology from tobacco waste product can occur rapidly.
\end{abstract}

Keywords : technological innovation, perception, botanical pesticide, characteristics of innovation.

\section{PENDAHULUAN}

Tanaman tembakau merupakan salah satu komoditas perkebunan berumur pendek atau musiman yang banyak diusahakan oleh petani dan menjadi komoditas unggulan di Kabupaten Sumedang. Luas tanaman tembakau di Kabupaten Sumedang pada tahun 2011 tercatat seluas 2.496 ha dengan produksi hasil olahan sebanyak 2.260 ton tembakau rajangan kering dengan rata-rata produksi $0,91 \mathrm{ton} / \mathrm{ha}$, yang melibatkan petani sebanyak 9.465 orang. Sentra pengolahan tembakau di Kabupaten Sumedang adalah Kecamatan Sukasari dan Tanjungsari. Minat petani untuk mengembangkan tembakau pada saat ini sangat besar mengingat dalam melaksanakan usahanya cepat memberikan hasil, adanya fasilitas pasar agribisnis tembakau Tanjungsari dan harga jualnya menarik, harga jual pada tahun 2011 rata-rata $\mathrm{Rp} 30.000,00$ s.d. $75.000,00 / \mathrm{kg}$ tembakau rajangan kering (Dinas Kehutanan dan Perkebunan Kabupaten Sumedang, 2012).
Kegiatan pengolahan tembakau menjadi tembakau rajangan kering dilaksanakan sepanjang tahun, karena tersedianya bahan baku daun tembakau. Selain dari daerah Sumedang, sumber bahan baku (daun tembakau basah) diperoleh dari daerah-daerah penghasil tembakau di wilayah Jawa Barat seperti Kabupaten Majalengka, Garut, Ciamis (Banjar), Kabupaten Bandung dan sebagainya. Jumlah bahan baku tembakau basah yang diolah/dirajang menjadi tembakau iris halus rata-rata $65 \mathrm{~kg}$ /hari/anggota kelompok. Dari $65 \mathrm{~kg}$ daun basah tembakau dihasilkan limbah berupa batang daun (pakang) sebanyak $15-20 \mathrm{~kg}$. Pada saat ini limbah tersebut belum dimanfaatkan secara optimal. Batang daun/pakang tembakau tersebut biasanya disimpan di pinggir kebun dan setelah busuk dimanfaatkan sebagai pupuk. Padahal, jika limbah tersebut bisa dimanfaatkan secara optimal, maka banyak dampak positif yang ditimbulkan seperti termanfaatkannya potensi sumberdaya lokal (limbah) menjadi bahan yang mempunyai 
nilai ekonomi (nilai tambah), dapat menumbuhkan wirausaha-wirausaha baru di daerah perdesaan dan dapat meningkatkan pendapatan para pengolah tembakau dari produk yang berbahan baku limbah tembakau.

Salah satu upaya yang telah dilakukan untuk memanfaatkan limbah tembakau tersebut adalah dengan pelatihan membuat pestisida nabati yang dilaksanakan oleh Tim Pengabdian Kepada Masyarakat, Sekolah Ilmu dan Teknologi Hayati, ITB. Pestisida nabati limbah tembakau merupakan salah satu jenis pestisida nabati yang ramah lingkungan, aman bagi manusia dan ekosistemnya sehingga dapat mendukung pertanian yang berkelanjutan. Walaupun pestisida nabati lebih unggul dari aspek kesehatan dan lingkungan dibandingkan dengan pestisida kimia, namun sebagai inovasi baru maka dibutuhkan suatu proses pemahaman (persepsi) untuk bisa diadopsi oleh para petani. Adopsi pestisida nabati oleh petani pengolah tembakau di Kabupaten Sumedang sebagai suatu proses hingga akhirnya petani memutuskan untuk mengadopsi atau tidak mengadopsi inovasi tersebut dipengaruhi oleh banyak faktor, misalnya faktor internal dan eksternal. Suatu inovasi akan diadopsi oleh petani jika mereka mempunyai persepsi yang baik terhadap inovasi tersebut. Oleh karena itu, tujuan penelitian ini akan mengkaji bagaimana persepsi petani terhadap teknologi pestisida nabati limbah tembakau.

\section{Persepsi Petani terhadap Inovasi}

Berdasarkan Oxford Dictionaries (2013) persepsi adalah kemampuan untuk melihat, mendengar, atau mengetahui sesuatu melalui indera. Mulyana (2004) menyatakan bahwa persepsi menyangkut kognisi yang mencakup kegiatan mental (otak), penafsiran objek, tanda, orang serta pengalaman yang bersangkutan. Adesina and Zinnah (1993) menyatakan bahwa persepsi adopter terhadap inovasi teknologi mempengaruhi proses adopsi inovasi teknologi yang diusulkan. Jika persepsi adopter positif, maka inovasi teknologi tersebut cenderung lebih cepat diadopsi.

Rogers dan Shoemaker (1971) mengartikan inovasi sebagai gagasan, tindakan atau barang yang dianggap baru oleh seseorang. Tidak menjadi soal, sejauh dihubungkan dengan tingkah laku manusia, apakah ide itu betul-betul baru atau tidak jika diukur dengan selang waktu sejak dipergunakan atau diketemukannya pertama kali. Kebaruan inovasi itu diukur secara subyektif, menurut pandangan individu yang menangkapnya. Mardikanto (1993), mendefinisikan inovasi adalah sesuatu ide, perilaku, produk, informasi, dan praktek-praktek baru yang belum banyak diketahui, diterima dan digunakan/ diterapkan, dilaksanakan oleh sebagian besar warga masyarakat dalam suatu lokalitas tertentu, yang dapat digunakan atau mendorong terjadinya perubahan-perubahan di segala aspek kehidupan masyarakat demi selalu terwujudnya perbaikan-perbaikan mutu hidup setiap individu dan seluruh warga masyarakat yang bersangkutan.
Selanjutnya Mardikanto (1993) mendefinisikan adopsi sebagai proses perubahan perilaku yang berupa pengetahuan (cognitive), sikap (afective) maupun keterampilan (pikomotorik) pada diri seseorang setelah menerima pesan yang disampaikan penyuluh pada sasaranya. Menurut Rogers (1995), keputusan individu untuk mengadopsi suatu inovasi tidak langsung tetapi mengikuti proses yang terdiri dari urutan tindakan dan keputusan yang terjadi dari waktu ke waktu.

Seseorang menerima suatu hal atau ide baru selalu melalui tahapan-tahapan. Samsudin (1982) dan Mardikanto (1993), menjelaskan bahwa tahapan proses adopsi adalah:

1) Tahap kesadaran. Petani mulai sadar tentang adanya sesuatu yang baru, mulai terbuka akan perkembangan dunia luarnya, sadar apa yang sudah ada dan apa yang belum.

2) Tahap minat. Tahap ini ditandai oleh adanya kegiatan mencari keterangan-keterangan tentang hal-hal yang baru diketahuinya.

3) Tahap penilaian. Setelah keterangan yang diperlukan diperoleh, mulai timbul rasa menimbang-nimbang untuk kemungkinan melaksanakannya sendiri.

4) Tahap mencoba. Jika keterangan sudah lengkap, minat untuk meniru besar, dan jika ternyata hasil penilaiannya positif, maka dimulai usaha mencoba hal baru yang sudah diketahuinya.

5) Tahap adopsi. Petani sudah mulai mempraktekkan hal-hal baru dengan keyakinan akan berhasil.

Sedangkan Rogers (1995) menyatakan tahapan proses adopsi inovasi sebagai berikut:

1) Tahap munculnya pengetahuan (Knowledge), dimana seseorang mengetahui adanya inovasi dan memperoleh beberapa pengertian tentang bagaimana inovasi itu berfungsi.

2) Tahap persuasi (Persuasion), dimana seseorang membentuk sikap berkenan atau tidak berkenan terhadap inovasi. Dasar dari proses pengetahuan dan persuasi tersebut identik dengan persepsi.

3) Tahap keputusan (Decisions), dimana seseorang terlibat dalam kegiatan yang membawanya pada pemilihan untuk menerima atau menolak inovasi.

4) Tahapan Implementasi (Implementation), dimana seseorang menetapkan penggunaan inovasi. Penemuan kembali (re-invention) sangat mungkin terjadi pada tahap pelaksanaan.

5) Tahapan Konfirmasi (Confirmation), dimana seseorang mencari penguatan bagi keputusan inovasi yang telah dibuatnya. Pada tahap ini mungkin terjadi seseorang merubah keputusannya jika ia memperoleh informasi yang bertentangan.

Pengambilan keputusan untuk mengadopsi suatu inovasi dipengaruhi oleh beberapa faktor. Rogers dan Shoemaker (1971) menyatakan bahwa keputusan menolak atau menerima inovasi teknologi ditentukan oleh faktor-faktor sosial dan ekonomi petani itu sendiri. Menurut Mardikanto (1993), kecepatan adopsi dipengaruhi oleh banyak faktor, yaitu: (a) sifat 
inovasinya sendiri, baik sifat intrinsik (yang melekat pada inovasinya sendiri) maupun sifat ekstrinsik (menurut atau dipengaruhi oleh keadaan lingkungan), (b) sifat sasarannya, (c) cara pengambilan keputusan, (d) saluran komunikasi yang digunakan, (e) keadaan penyuluh. Berkaitan dengan kemampuan penyuluh untuk berkomunikasi, perlu juga diperhatikan kemampuan berempati atau kemampuan untuk merasakan keadaan yang sedang dialami atau perasaan orang lain, (f) ragam sumber informasi.

Tingkat adopsi dari suatu inovasi tergantung pada persepsi adopter tentang karakteristik inovasi tek nologi tersebut (Rogers, 1995). Ada lima karakteristik yang mendukung penjelasan tingkat adopsi dari suatu inovasi yaitu:

1) Keuntungan-keuntungan relatif(relatif advantages); yaitu sejauhmana suatu inovasi dianggap lebih baik daripada inovasi sebelumnya. Keuntungan relatif ini meliputi tingkat profitabilitas ekonomi, biaya yang rendah, rasa nyaman, penghematan waktu dan usaha serta insentif.

2) Kesesuaian (compatibility); yaitu apakah inovasi mempunyai sifat lebih sesuai dengan nilai yang ada, pengalaman sebelumnya, dan kebutuhan yang diperlukan penerima/adopter.

3) Kerumitan (complexity); yakni apakah inovasi tersebut dirasakan rumit untuk dipahami dan digunakan.

4) Dapat dicobakan (triability); yaitu suatu inovasi akan mudah diterima apabila dapat dicobakan dalam ukuran kecil.

5) Dapat dilihat (observability); yaitu suatu inovasi dapat disaksikan dengan mata. Semakin mudah bagi individu untuk melihat hasil sebuah inovasi, semakin besar kemungkinan mereka untuk mengadopsi.

Beberapa hasil penelitian menunjukkan bahwa persepsi adopter tentang sifat/karakteristik inovasi dapat mempengaruhi tingkat adopsi dari suatu inovasi. Seperti penelitian Alisa (2007) menunjukkan bahwa inovasi untuk menggunakan pupuk kompos kotoran ternak dipersepsikan petani sebagai inovasi yang memiliki sifat memberikan keuntungan relatif, kesesuaian, kerumitan, kemudahan dapat dicoba dan diamati. Kemudian Prabayanti (2010) meneliti tentang faktor-faktor yang mempengaruhi adopsi biopestisida oleh petani di Kecamatan Mojogedang Kabupaten Karanganyar. Hasil penelitian tersebut menyimpulkan bahwa semakin baik persepsi terhadap sifat inovasi maka peluang inovasi tersebut untuk diadopsi semakin tinggi pula.

\section{Pestisida Nabati}

Pestisida nabati merupakan produk alam dari tumbuhan seperti daun, bunga, buah, biji, kulit, dan batang yang mempunyai kelompok metabolit sekunder atau senyawa bioaktif. Tumbuhan mengandung banyak bahan kimia yang merupakan metabolit sekunder dan digunakan oleh tumbuhan sebagai alat pertahanan dari serangan organisme pengganggu. Tumbuhan sebenarnya kaya akan bahan bioaktif, walaupun han- ya sekitar 10.000 jenis produksi metabolit sekunder yang telah teridentifikasi, tetapi sesungguhnya jumlah bahan kimia pada tumbuhan dapat melampaui 400.000 jenis (Asmaliyah, dkk, 2010). Selanjutnya menurut Grainge et al., 1984 dalam Sastrosiswojo (2002), ada 1800 jenis tanaman yang mengandung pestisida nabati yang dapat digunakan untuk pengendalian hama. Di Indonesia, sebenarnya sangat banyak jenis tumbuhan penghasil pestisida nabati, dan diperkirakan ada sekitar 2400 jenis tanaman yang termasuk ke dalam 235 famili (Kardinan, 2000). Pemanfaatan tumbuhan penghasil pestisida nabati dalam pengendalian hama sudah banyak dilakukan, terutama di bidang pertanian dan perkebunan dan hasilnya efektif. Penggunaan suatu pestisida nabati akan lebih baik hasilnya atau lebih efektif apabila dipadukan dengan pestisida nabati lainnya. Aplikasinya dapat dilakukan secara pencampuran atau secara berselang-seling, misal ekstrak daun sirsak dan ekstrak biji mimba. Penggunaan pestisida nabati juga dapat dipadukan dengan musuh alami bila bahan pestisida nabati tersebut tidak beracun bagi musuh alami (Asmaliyah, dkk, 2010).

Salah satu jenis tanaman yang dapat dimanfaatkan sebagai pestisida nabati adalah tembakau. Bagian tembakau yang dapat dimanfaatkan untuk pestisida nabati yaitu batang dan daun. Selain tembakau, tanaman yang dimanfaatkan untuk pestisida nabati di antaranya mimba,daun sirsak, biji srikaya, mahoni, kecubung, mindi, brotowali, biji bengkuang, sambiloto, dan lain-lain.

Beberapa hasil penelitian pemanfaatan ekstrak nabati yang mengandung senyawa bioaktif selain berpengaruh pada aktivitas makan juga berpengaruh terhadap penghambatan aktivitas peneluran, perkembangan telur, larva, dewasa, penghambat pembentukan khitin, kematian, dan mengganggu sistem reproduksi (Isman 1995; Schmutterer 1995). Hasil penelitian Rudiyanti (2010) tentang toksisitas ekstrak daun tembakau (nicotina tobacum) terhadap pertumbuhan ikan nila, menyimpulkan bahwa ekstrak daun tembakau termasuk pestisida alami yang mempunyai daya racun sedang. Pemberian ekstrak daun tembakau pada konsentrasi subletal berpengaruh terhadap pertumbuhan biomassa mutlak dan laju pertumbuhan harian benih ikan nila. Selanjutnya hasil pengujian Harwanto, dkk (2012) tentang pengaruh ekstrak limbah daun tembakau Madura terhadap aktivitas makan larva Spodoptera exigua, menunjukkan bahwa ekstrak limbah daun tembakau Madura berpengaruh negatif terhadap aktivitas makan larva instar III S. exigua yang ditunjukkan oleh rendahnya bobot daun yang dikonsumsi dan persentase hambatan makannya semakin tinggi.

Keuntungan menggunakan pestisida nabati dibandingkan pestisida kimia antara lain meminimalkan terjadinya kerusakan lingkungan hidup, tidak membahayakan makhluk lain yang bukan sasaran, seperti predator, parasitoid, serangga penyerbuk, dan serangga berguna lebah madu (Trubus, 2009 dalam Prabayanti, 2010). Selanjutnya Suwahyono (2010) 
menyatakan bahwa pestisida nabati sangat bermanfaat baik dari aspek sosial ekonomi maupun aspek lingkungan. Ditinjau dari aspek sosial ekonomi, pestisida nabati merupakan salah satu faktor yang menentukan dalam upaya menurunkan biaya produksi sehingga secara tidak langsung dapat meningkatkan pendapatan petani. Ditinjau dari aspek lingkungan, pestisida nabati dapat mengurangi dampak negatif dari penggunaan pestisida kimia seperti terjadinya degradasi lingkungan, adanya residu bahan kimia didalam tanah dan terakumulasi di dalam jaringan tanaman dan tetap bertahan sampai dikonsumsi oleh manusia maupun hewan serta menurunnya biota tanah.

\section{METODE}

Penelitian ini dilakukan di Kelompok tani Gunasari 2, Desa Sukasari Kecamatan Sukasari dan Kelompok tani Mekarjaya di Desa Pasigaran Kecamatan Tanjungsari Kabupaten Sumedang pada bulan Agustus sampai Oktober 2013. Pemilihan lokasi dilakukan secara sengaja (purposive) dengan pertimbangan bahwa kedua kelompok tersebut merupakan kelompok tani yang secara terus menerus mengolah tembakau menjadi tembakau iris/kering, sehingga bahan baku untuk pembuatan pestisida nabati limbah tembakau selalu tersedia, dan anggota kelompok tani di kedua kelompok tersebut telah mendapat pelatihan pemanfaatan limbah tembakau menjadi pestisida nabati yang dilaksanakan oleh Tim Pengabdian Kepada Masyarakat, Sekolah Ilmu dan Teknologi Hayati, Institut Teknologi Bandung.

Metode yang digunakan dalam penelitian ini adalah metode deskriptif. Metode deskriptif yaitu pencarian fakta dengan interpretasi yang tepat. Penelitian deskriptif mempelajari masalah-masalah dalam masyarakat, tata cara yang berlaku dalam masyarakat serta situasi-situasi tertentu, termasuk tentang hubungan, kegiatan-kegiatan, sikap-sikap, pandangan-pandangan, serta proses-proses yang sedang berlangsung dan pengaruh-pengaruh dari suatu fenomena. Teknik penelitian yang digunakan adalah teknik studi kasus, yaitu penelitian tentang status subjek penelitian (individu, kelompok, lembaga, masyarakat) yang berkenaan dengan suatu fase spesifik atau khas dari keseluruhan personalitas (Nazir, 1988).

Penentuan responden dilakukan secara sensus terhadap seluruh anggota kedua kelompok tersebut yang mengikuti pelatihan teknologi pestisida nabati limbah tembakau yaitu Kelompok tani Gunasari 2 sebanyak 20 orang dan Kelompok tani Mekarjaya sebanyak 20 orang.

Data yang digunakan adalah data primer yang diambil dengan menggunakan kuesioner. Data primer meliputi karakteristik petani dan persepsi petani terhadap inovasi teknologi pestisida nabati limbah tembakau. Persepsi petani terhadap inovasi teknologi pestisida nabati limbah tembakau diukur dengan menggunakan skala likert dengan skor 1 (sangat tidak setuju), skor 2 (tidak setuju), skor 3 (ragu-ragu), skor 4 (setuju) dan skor 5 (sangat setuju), kemudian data tersebut dianalisis dengan menghitung:

a. Skor maksimal yaitu skor jawaban terbesar dikali banyaknya item/indikator

b. Skor minimum yaitu skor jawaban terkecil dikali banyaknya item/indikator

c. Nilai median (Me)yaitu hasil penjumlahan skor maksimum dengan skor minimum dibagi 2

d. Nilai kuartil ke satu (K1) yaitu hasil penjumlahan skor minimum dengan nilai median dibagi 2

e. Nilai kuartil ke tiga (K3) yaitu hasil penjumlahan skor maksimum dengan median dibagi 2

Berdasarkan perhitungan tersebut, maka persepsi petani terhadap inovasi teknologi pestisida nabati limbah tembakau dikategorikan sebagai berikut:

a. Sangat positif : $\mathrm{K} 3 \leq \mathrm{X} \leq$ skor maks

b. Positif : $\mathrm{Me} \leq \mathrm{X}<\mathrm{K} 3$

c. Negatif : $\mathrm{K} 1 \leq \mathrm{X}<\mathrm{Me}$

d. Sangat negatif : Skor $\min \leq \mathrm{X}<\mathrm{K} 1$ (Jainuri,2014)

\section{HASIL DAN PEMBAHASAN}

\section{Karakteristik Responden}

Karakteristik responden dalam penelitian ini meliputi umur, pengalaman berusahai tembakau, luas lahan garapan, pendidikan, status penguasaan lahan dan pendapatan. Tabel 4.1 memperlihatkan bahwa umur produktif petani responden pada umumnya berumur 30 - 55 tahun (60\%). Jika dilihat berdasarkan penggolongan umur produktif dan tidak produktif, maka sebagian besar petani responden berada dalam kategori umur produktif, yang berarti sangat berpeluang dalam upaya peningkatan produktivitas usaha mereka karena umur produktif sangat berpengaruh dengan kemampuan fisik petani untuk bekerja secara optimal.

Pengalaman petani dalam berusaha berpengaruh terhadap cara merespon suatu inovasi. Semakin lama pengalaman berusaha, maka tingkat respon terhadap suatu teknologi akan semakin tinggi. Pengalaman berusaha sangat penting dalam rangka pengelolaan usahatani, baik dalam pengambilan keputusan pemilihan komoditas yang ditanam maupun dalam penggunaan faktor produksi. Kenyataan menunjukkan bahwa semakin berpengalaman petani dalam berusaha, cenderung semakin efisien dalam mengalokasikan faktor produksi dalam usaha tersebut. Proporsi terbesar dari responden adalah petani yang memiliki pengalaman di atas 10 tahun. Hal ini memberikan indikasi bahwa tembakau sejak lama telah diusahakan dan dipilih oleh petani secara terus menerus sebagai salah satu sumber pendapatan.

Pendidikan formal merupakan lama pendidikan yang ditempuh responden pada bangku sekolah. Tingkat pendidikan formal petani sangat berpengaruh terhadap kemampuan dalam merespon suatu inovasi. Makin tinggi tingkat pendidikan formal petani diharapkan makin rasional dalam pola pikir dan juga daya nalarnya. Dengan pendidikan yang semakin tinggi diharapkan dapat lebih mudah merubah sikap dan perilaku untuk bertindak lebih rasional. Sebagian besar petani responden telah menempuh pendidikan formal walaupun masih tergolong pada 
Tabel 1. Karakteristik Responden

\begin{tabular}{|c|c|c|c|}
\hline No & Karakteristik & Jumlah & $\%$ \\
\hline \multirow[t]{4}{*}{$\overline{1}$} & Umur (tahun) & & \\
\hline & $\leq 30$ & 10 & 25 \\
\hline & $30-55$ & 24 & 60 \\
\hline & $>55$ & 6 & 15 \\
\hline \multirow[t]{4}{*}{2} & Pengalaman mengusahakan/mengolah te & & \\
\hline & $\leq 10$ & 5 & 13 \\
\hline & $10-20$ & 15 & 38 \\
\hline & $>20$ & 20 & 50 \\
\hline \multirow[t]{4}{*}{3} & Luas pengusahaan tembakau: (ha) & & \\
\hline & $\leq 0,5$ & 19 & 48 \\
\hline & $0,51-1,0$ & 14 & 35 \\
\hline & $>1,0$ & 7 & 18 \\
\hline \multirow[t]{5}{*}{4} & Pendidikan : & & \\
\hline & Tidak tamat SD & 10 & 25 \\
\hline & SD & 15 & 38 \\
\hline & SMP & 9 & 23 \\
\hline & SMA & 6 & 15 \\
\hline \multirow[t]{4}{*}{5.} & Status Penguasaan Lahan: & & \\
\hline & Pemilik & 10 & 25 \\
\hline & Penyewa & 24 & 60 \\
\hline & Gadai & 6 & 15 \\
\hline \multirow[t]{4}{*}{6.} & Pendapatan / bulan & & \\
\hline & $<1.5000 .000$ & 5 & 13 \\
\hline & $1.500 .000-3.000 .000$ & 25 & 63 \\
\hline & $>3.000 .000$ & 10 & 25 \\
\hline
\end{tabular}

tingkat pendidikan SD, sehingga dapat dikatakan sumberdaya manusia (SDM) petani masih tergolong rendah, sebab tingkat pendidikan seseorang menentukan keberhasilan dalam mengelolah usahataninya.

Luas penguasaan lahan merupakan keseluruhan luas lahan yang diusahakan petani responden baik milik sendiri, menyewa, maupun gadai. Luas penguasaan lahan akan berpengaruh terhadap adopsi inovasi. Hal ini disebabkan karena luas penguasaan lahan akan mempengaruhi banyaknya pendapatan yang diterima oleh petani. Semakin luas penguasaan lahan yang digunakan untuk kegiatan usahatani maka akan semakin tinggi pula hasil produksinya. Hernanto (1993) menyebutkan, luas lahan usahatani menentukan pendapatan, taraf hidup dan derajat kesejahteraan rumah tangga tani. Hal tersebut tentunya akan turut meningkatkan pendapatan usahatani sehingga meningkatkan adopsi terhadap suatu inovasi.

Responden mempunyai lahan luas dan sedang $(52,50 \%)$ serta sempit $(47,50 \%)$. Hal tersebut akan berpengaruh terhadap adopsi inovasi pestisida nabati. Pada umumnya petani yang memiliki lahan sempit cenderung kurang berani mencoba suatu inovasi karena takut gagal. Lain halnya dengan petani yang memiliki lahan luas, mereka cenderung berani mencoba inovasi pada sebagian kecil lahannya tanpa takut gagal karena masih memiliki sebagian besar luas lahannya yang tidak dicobakan suatu inovasi. Status penguasaan lahan yang digunakan untuk usahatani tembakau didominasi oleh status sewa.

Pendapatan merupakan pendapatan total yang diperoleh responden baik dari kegiatan usahatani dan pengolahan tembakau maupun luar usahatani. Petani dengan pendapatan yang tinggi akan cenderung lebih cepat untuk menerima dan menerapkan suatu inovasi karena seseorang dengan pendapatan tinggi cenderung lebih berani mencoba hal-hal baru yang ada di sekitar mereka. Selain pendapatan dari usahatani tembakau dan pengolahan daun tembakau, sebagian petani juga memperoleh pendapatan dari usahatani padi, singkong, ubi jalar, pisang, dan sayuran serta pendapatan dari luar usahatani tersebut seperti menjadi buruh tani, tukang ojeg, pegawai negeri dan pedagang.

\section{Persepsi Petani terhadap Inovasi Teknologi Pestisida Nabati Limbah Tembakau}

Persepsi petani terhadap inovasi teknologi pestisida nabati limbah tembakau diukur dari persepsi petani terhadap sifat/karakteristik inovasi tersebut yaitu persepsi terhadap relative advantage (keuntungan relatif), compatibility (kesesuaian), complexity (kerumitan), triability (ketercobaan), dan observability (keteramatan). Untuk lebih jelasnya dapat diuraikan sebagai berikut:

\section{Persepsi terhadap Relative Advantage (Keuntungan Relatif) Pestisida Nabati Limbah Tembakau}

Salah satu pertimbangan petani untuk mengadopsi suatu inovasi adalah apabila inovasi tersebut menguntungkan bagi calon adopternya. Persepsi petani terhadap keuntungan relatif pestisida nabati dapat dilihat dari dua indikator yaitu biaya pembuatan pestisida nabati limbah tembakau lebih murah daripada pestisida kimia sehingga dapat menghemat biaya produksi dan pestisida nabati lebih unggul dilihat dari aspek keamanan terhadap kesehatan dan

\begin{tabular}{lccc}
\hline $\begin{array}{c}\text { Kategori } \\
\text { persepsi }\end{array}$ & $\begin{array}{c}\text { Kategori } \\
\text { Skor }\end{array}$ & $\begin{array}{c}\text { Jumlah } \\
\text { Responden }\end{array}$ & $\begin{array}{c}\text { Persen } \\
(\%)\end{array}$ \\
\hline Sangat & $8-10$ & 2 & 5 \\
positif & & & \\
Positif & $6-8$ & 32 & 80 \\
Negatif & $4-6$ & 6 & 15 \\
Sangat & $2-4$ & 0 & 0
\end{tabular}

Negatif

lingkungan dibandingkan pestisida kimia. Persepsi responden terhadap keuntungan relatif pestisida nabati dapat dilihat pada Tabel 2 .

Tabel 2. Persepsi Petani terhadap Keuntungan Relatif Inovasi Pestisida Nabati Limbah Tembakau

Berdasarkan Tabel 2 dapat dilihat bahwa persepsi petani terhadap keuntungan relatif inovasi pestisida nabati sebagian besar positif (80\%). Petani menilai bahwa biaya pembuatan pestisida nabati tergolong murah dibandingkan dengan biaya pembelian pestisida kimia yang semakin mahal. Oleh sebab itu, penggunaan pestisida nabati menjadi solusi bagi petani dalam menghadapi masalah keterbatasan modal untuk pembelian pestisida kimia. Rendahnya biaya produksi untuk membuat pestisida nabati disebabkan bahan-bahan untuk pembuatan pestisida nabati tersebut berasal dari limbah tembakau (batang dan sisa-sisa daun tembakau) yang selama ini tidak dimanfaatkan secara optimal. Selain limbah tembakau, bahan-bahan lainnya yang digunakan untuk campuran pembuatan pestisida nabati banyak tersedia di lingkungan sekitar seperti daun sirsak, daun mindi, kecubung, nimba dsb. Selain ketersediaannya cukup banyak, tanaman-tanaman tersebut sudah dikenal oleh petani di daerah penelitian. Suwahyono (2010) dan Prabayanti (2010) berpendapat bahwa rendahnya biaya pembuatan pestisida nabati tersebut 
menyebabkan biaya usahatani lebih rendah sehingga keuntungan yang diperoleh petani menjadi lebih tinggi.

Petani menilai pestisida nabati ini juga lebih ung gul dibandingkan dengan pestisida kimia dalam aspek keamanan bagi kesehatan dan lingkungan serta efektifitas dalam membasmi hama karena kandungan bahan-bahan aktif yang ada pada bahan baku pestisida nabati tersebut bersifat racun bagi hama tanaman walaupun jarang menyebabkan kematian. Pestisida nabati juga tidak membunuh hewan-hewan yang bukan termasuk golongan hama tanaman (Kardinan, 2000). Hal tersebut tentunya dapat mengurangi kerugian kehilangan hasil panen akibat serangan hama maupun penyakit tanaman. Selain itu, hasil penelitian Prabayanti (2010) menyebutkan bahwa inovasi biopestisida yang ramah lingkungan dapat membantu pemenuhan kebutuhan pangan yang sehat dan terhindar dari zat-zat beracun karena residu penggunaan biopestisida cepat hilang.

\section{Persepsi Petani terhadap Compatibility (Kese- suaian) Pestisida Nabati Limbah Tembakau}

Pada penelitian ini, persepsi petani terhadap kesesuaian pestisida nabati limbah tembakau dilihat dari kesesuaian inovasi pestisida nabati limbah tembakau dengan kondisi dan kebiasaan masyarakat

(petani) setempat, kebutuhan petani, dan keadaan lingkungan. Persepsi responden terhadap kesesuaian

\begin{tabular}{lccc}
\hline $\begin{array}{l}\text { Kategori } \\
\text { persepsi }\end{array}$ & $\begin{array}{c}\text { Kategori } \\
\text { Skor }\end{array}$ & $\begin{array}{c}\text { Jumlah } \\
\text { Responden }\end{array}$ & $\begin{array}{c}\text { Persen } \\
(\%)\end{array}$ \\
\hline Sangat & $12-15$ & 13 & 32,5 \\
positif & & & \\
Positif & $9-12$ & 23 & 57,5 \\
Negatif & $6-9$ & 4 & 10 \\
Sangat & $3-6$ & 0 & 0 \\
Negatif & & & \\
\hline
\end{tabular}

pestisida nabati dapat dilihat pada Tabel 3.

Tabel 3. Persepsi Petani terhadap Kesesuaian Inovasi Pestisida Nabati Limbah Tembakau

Berdasarkan Tabel 3 dapat diketahui bahwa petani responden menilai positif $(57.5 \%)$ dan $32,5 \%$ menilai sangat positif terhadap inovasi pestisida nabati. Pestisida nabati memiliki kesesuaian yang baik dengan kondisi dan kebiasaan masyarakat setempat dimana pestisida nabati dapat dibuat sendiri oleh petani dan bahan baku untuk membuat pestisida nabati tersebut sudah dikenal dan tersedia di wilayah sekitarnya sehingga tidak membutuhkan biaya yang banyak. Selain itu, penggunaannya juga tidak merubah kebiasaan petani dalam menggunakan alat semprot karena pestisida nabati dapat diaplikasikan dengan menggunakan alat semprot (sprayer) gendong seperti pestisida kimia pada umumnya.

Kesesuaian dengan kebutuhan petani yaitu saat ini sebagian besar petani sudah menyadari dan merasakan dampak negatif pemakaian pestisida kimia yang terus menerus sehingga mereka membutuhkan inovasi untuk mengendalikan organisme pengganggu tanaman (OPT) yang ramah lingkungan. Walaupun petani menganggap kecepatan pengendalian pestisida nabati tersebut tidak secepat pestisida kimia, namun para petani sudah menyadari bahwa penggunaan pestisida kimia berpengaruh tidak baik terhadap kesehatan dan lingkungan. Selain itu, ketersediaan pestisida kimia di tingkat lokal (desa) kadang-kadang sulit diperoleh dan harganya mahal.

Kesesuaian dengan kondisi lingkungan yaitu masyarakat (petani) tidak merasa khawatir dengan dampak yang ditimbulkan apabila menggunakan pestisida nabati, karena mereka merasa yakin bahwa pestisida nabati tidak akan merusak lingkungan. Beberapa hasil penelitian sebelumnya menyimpulkan bahwa pada saat ini penggunaan pestisida kimia yang berlebihan menyebabkan pencemaran lingkungan, sedangkan residu dari penggunaan pestisida nabati segera hilang sehingga tidak akan berdampak buruk bagi lingkungan baik udara, tanah maupun biota tanah (Prabayanti, 2010; Suwahyono, 2010). Menurut Kardinan (2011), untuk menuju sistem pertanian organik, pestisida nabati merupakan alternatif untuk mengurangi dampak negatif pestisida sintetis.

\section{Persepsi Petani terhadap Complexity (Kerumitan) Pestisida Nabati Limbah Tembakau}

Kerumitan suatu inovasi dapat mempengaruhi cepat tidaknya seseorang mengadopsi inovasinya. Kerumitan pestisida nabati limbah tembakau dapat dilihat melalui persepsi petani terhadap inovasi tersebut yang meliputi sulit tidaknya pemahaman petani dalam membuat dan mengaplikasikan pestisida nabati tersebut. Persepsi responden terhadap kerumitan pestisida nabati dapat dilihat pada Tabel 4 berikut:

\begin{tabular}{lccc}
\hline $\begin{array}{c}\text { Kategori } \\
\text { persepsi }\end{array}$ & Kategori Skor & $\begin{array}{c}\text { Jumlah } \\
\text { Responden }\end{array}$ & Persen (\%) \\
\hline Sangat positif & $8-10$ & 11 & 27,5 \\
Positif & $6-8$ & 26 & 65 \\
Negatif & $4-6$ & 3 & 7,5 \\
Sangat & $2-4$ & 0 & 0 \\
Negatif & & & \\
\hline
\end{tabular}

Tabel 4. Persepsi Petani terhadap Complexity (Kerumitan) Inovasi Pestisida Nabati Limbah Tembakau

Berdasarkan Tabel 4 dapat dilihat bahwa sebagian besar petani $(65 \%)$ menilai positif terhadap tingkat kerumitan inovasi pestisida nabati limbah tembakau, artinya pemahaman petani terhadap pembuatan dan penggunaan (aplikasi) pestisida nabati termasuk tidak rumit (mudah). Cara pembuatannya pun mudah, hal ini dilihat dari aspek ketersediaan bahan baku dan keterampilan petani. Bahan-bahan pembuatan pestisida nabati limbah tembakau sangat mudah diperoleh di sekitar wilayahnya dan bahan-bahan tersebut juga selalu tersedia. Limbah tembakau berupa batang dan sisa-sisa daun dari proses rajangan tersedia cukup banyak di daerah penelitian. Cara pembuatan pestisida nabati limbah tembakau tidak memerlukan keterampilan khusus, namun memerlukan ketelatenan karena proses pembuatannya memerlukan waktu 
yang cukup lama (sekitar 1-2 hari), sehingga ada 3 orang petani $(7,5 \%)$ yang menyatakan bahwa cara pembuatan dan penggunaan pestisida nabati limbah tembakau tersebut tidak praktis.

Penggunaan pestisida nabati tidak menyulitkan petani karena cara penggunaan pestisida nabati tidak jauh berbeda dengan penggunaan pestisida kimia yaitu pestisida nabati limbah tembakau cair dicampur dengan air kemudian disemprotkan ke tanaman dengan menggunakan alat semprot (sprayer).

\section{Persepsi Petani terhadap Triability (Ketercobaan) Pestisida Nabati}

Sebelum suatu inovasi diadopsi oleh petani hendaknya suatu inovasi dapat dicobakan secara terbatas (dalam skala yang lebih kecil). Petani juga akan lebih percaya pada suatu inovasi ketika suatu inovasi dapat dicoba atau mungkin telah dicoba oleh petani lain dan memiliki tingkat keberhasilan. Adapun persepsi petani responden terhadap ketercobaan pestisida nabati adalah sebagai berikut:

\begin{tabular}{lccc}
\hline $\begin{array}{c}\text { Kategori } \\
\text { persepsi }\end{array}$ & $\begin{array}{c}\text { Kategori } \\
\text { Skor }\end{array}$ & $\begin{array}{c}\text { Jumlah } \\
\text { Responden }\end{array}$ & Persen (\%) \\
\hline Sangat positif & $12-15$ & 19 & 47,5 \\
Positif & $9-12$ & 21 & 52,5 \\
Negatif & $6-9$ & 0 & 0 \\
Sangat & $3-6$ & 0 & 0 \\
Negatif & & & \\
\hline
\end{tabular}

Tabel 5. Persepsi Petani terhadap Ketercobaan Inovasi Pestisida Nabati

Berdasarkan Tabel 5 dapat diketahui bahwa sebagian besar petani menilai positif dan sangat positif terhadap ketercobaan pestisida nabati karena petani menilai inovasi pestisida nabati dapat dicoba sebelum benar-benar diadopsi oleh petani. Petani dapat mencoba membuat ramuan pestisida nabati limbah tembakau dengan teknologi yang sangat sederhana (mudah dan murah). Sebelum mengadopsi pestisida nabati limbah tembakau, petani dapat membuat pestisida nabati dalam takaran yang kecil semacam percobaan, kemudian diaplikasikan ke tanaman untuk mengendalikan hama pada lahan yang sempit. Pada penelitian ini, petani membuat pestisida nabati limbah tembakau secara berkelompok yaitu di kelompok tani Gunasari 2 dan kelompok tani Mekarjaya.

Beberapa teknik yang umum digunakan untuk mengolah pestisida nabati diantaranya dengan teknik merendam, mengekstrak dan ataupun merebus bagian batang dan atau daun tembakau. Contoh dengan teknologi sederhana adalah dengan cara mengeringkan batang dan atau sisa-sisa daun tembakau, menumbuk atau menggilingnya menjadi serbuk, kemudian serbuk direndam dalam air selama semalam, disaring dan langsung dapat diaplikasikan ke tanaman yang terserang hama dan atau penyakit.

Pestisida nabati limbah tembakau yang berupa larutan pestisida nabati cair juga dapat digunakan untuk mengendalikan beberapa jenis hama yang menyerang suatu pertanaman. Senyawa yang dikandung tembakau adalah nikotin. Susanti dan Boesri (2012) menyatakan, nikotin selain beracun untuk manusia, tetapi dapat dimanfaatkan juga untuk racun serangga. Nikotin merupakan racun syaraf yang bereaksi cepat. Nikotin berperan sebagai racun kontak bagi serangga seperti ulat perusak daun, aphids, triphs, dan pengendali jamur (fungisida).

\section{Persepsi Petani terhadap Observability (Ketera- matan) Pestisida Nabati Limbah Tembakau}

Keteramatan pestisida nabati di sini dapat dilihat melalui persepsi petani terhadap keunggulan dan kelemahan yang dapat diamati jika menggunakan inovasi teknologi pestisida nabati dan sejauhmana hasil penggunaan pestisida nabati disebarluaskan/dikomunikasikan kepada yang lain. Persepsi responden terhadap keteramatan pestisida nabati dapat dilihat pada Tabel 6 .

Berdasarkan Tabel 6. terlihat bahwa sebagian besar petani (70\%) memiliki persepsi positif terhadap keteramatan pestisida nabati. Pestisida nabati sebagai salah satu komponen dalam pengelolaan OPT pertanian memiliki kelebihan dan kelemahan. Berdasarkan hasil wawancara dengan petani, penggunaan pestisida nabati cukup aman untuk kesehatan petani, tidak mencemari lingkungan dan binatang/serangga yang menguntungkan bagi tanaman tidak ikut mati. Namun demikian proses pembuatan pestisida nabati cukup lama, daya racunnya rendah dan cepat hilang sehingga agar pestisida nabati tersebut efektif dalam mengendalikan hama dan penyakit tanaman maka penyemprotannya relatif harus sering.

Berdasarkan hasil penelitian Prabayanti (2010), petani juga dapat merasakan bahwa OPT yang menyerang tanaman mereka dapat efektif dikendalikan setelah menyemprotkan pestisida nabati pada tanaman yang terserang OPT walaupun kecepatan dalam mengendalikan OPT tidak secepat pestisida kimia, dan frekuensi penyemprotan harus berulang-ulang karena sifat pestisida nabati cepat terdegradasi.

\begin{tabular}{cccc}
\hline $\begin{array}{c}\text { Kategori } \\
\text { persepsi }\end{array}$ & $\begin{array}{c}\text { Kategori } \\
\text { Skor }\end{array}$ & $\begin{array}{c}\text { Jumlah } \\
\text { Responden }\end{array}$ & Persen (\%) \\
\hline $\begin{array}{c}\text { Sangat } \\
\text { positif }\end{array}$ & 08 -Okt & 10 & 25 \\
Positif & 06 -Agust & 28 & 70 \\
Negatif & $04-J u n$ & 2 & 5 \\
$\begin{array}{c}\text { Sangat } \\
\text { Negatif }\end{array}$ & $02-$ Apr & 0 & 0 \\
\hline
\end{tabular}

Tabel 6. Persepsi Petani terhadap Keteramatan Inovasi Pestisida Nabati Limbah Tembakau

Temuan penelitian ini mendukung beberapa hasil penelitian sebelumnya yang menyimpulkan bahwa kelebihan pestisida nabati antara lain cepat terdegradasi sehingga tidak meninggalkan residu dalam waktu lama, cara kerjanya cepat, daya racun terhadap binatang mamalia rendah, dan daya racun terhadap tanaman juga rendah (kurang fitotoksik). Sementara itu kekurangannya antara lain karena cepat terdegradasi maka memerlukan frekuensi 
aplikasi lebih sering, kurangnya sumber bahan baku, sulit untuk melakukan pengendalian kualitas dan standarisasi, kurangnya data terhadap berbagai hama dan sulitnya melakukan registrasi (Isman, 1997; Kardinan, 2000; Cloyd, 2004; Johnson, 2006).

Keberhasilan hasil aplikasi pestisida nabati dapat disebarluaskan kepada petani yang lain, baik dalam satu kelompok tani maupun antar kelompok tani, hal ini berkaitan dengan perilaku petani dimana jika ada suatu inovasi, mereka tidak akan cepat mengadopsinya tetapi mereka akan melihat dulu keberhasilannya. Semakin kelihatan atau terbukti keberhasilan suatu inovasi, maka semakin cepat petani mengadopsinya. Seperti pendapat Rogers (1995), keputusan individu untuk mengadopsi suatu inovasi tidak langsung tetapi mengikuti proses yang terdiri dari urutan tindakan dan keputusan yang terjadi dari waktu ke waktu.

\section{SIMPULAN}

Berdasarkan hasil penelitian dapat disimpulkan bahwa sebagian besar persepsi petani terhadap inovasi teknologi pestisida nabati limbah tembakau termasuk kriteria positif. Secara lebih rinci dapat digambarkan persepsi petani mengenai sifat-sifat inovasi teknologi pestisida nabati limbah tembakau yang terdiri atas:

Keuntungan relatif, sebagian besar (80\%) persepsi petani termasuk dalam kategori positif, artinya inovasi pestisida nabati memberikan beberapa keuntungan bagi petani yaitu biaya lebih murah dan lebih unggul daripada pestisida kimia.

Kesesuaian, sebagian besar $(57,5 \%)$ termasuk dalam kategori positif dan 32,5\% termasuk sangat positif artinya inovasi pestisida nabati cukup sesuai dengan kondisi dan kebiasaan masyarakat (petani), kebutuhan petani dan keadaan lingkungan.

Kerumitan, sebagian besar (65\%) termasuk dalam kategori positif dan $27,5 \%$ termasuk sangat positif artinya cara pembuatan pestisida nabati cukup mudah dipahami dan penggunaaannya tidak sulit.

Ketercobaan, sebagian besar (52,5\%) termasuk dalam kategori positif dan 47,5\% sangat positif, artinya inovasi pestisida nabati dapat dicoba oleh petani dalam takaran kecil dan dapat dicoba diaplikasikan pada lahan yang sempit.

Keteramatan, sebagian besar (70\%) termasuk dalam kategori positif dan $25 \%$ termasuk sangat positif, artinya keunggulan dan kelemahan inovasi pestisida nabati dapat diamati dan hasil pengaplikasian pada tanaman dapat disebarluaskan ke petani lain.

Para petani diharapkan dapat mengaplikasikan pestisida nabati limbah tembakau pada tanamantanaman yang terserang hama karena berdasarkan penelitian-penelitian sebelumnya, pestisida nabati berbahan baku tembakau cukup efektif mengendalikan organisme pengganggu tanaman (OPT). Para petani yang masih ragu-ragu untuk mengaplikasikan pestisida nabati limbah tembakau ini dapat mencoba membuat dalam skala kecil dan mengaplikasikannya pada tanaman atau melihat dulu keberhasilan petani lain (anggota kelompok tani) yang telah menggunakan pestisida nabati limbah tembakau ini.
Perlu dilakukan penelitian lanjutan mengenai efektifitas pestisida nabati limbah tembakau dalam mengendalikan organisme pengganggu tanaman(OPT) pada tanaman pangan, hortikultura, dan perkebunan.

\section{UCAPAN TERIMA KASIH}

Ucapan terima kasih disampaikan kepada DP2M Dikti yang telah memberi dana untuk kegiatan Pengabdian Pada Masyarakat melalui IbM Kelompok Tani Pengolah Tembakau Tahun Anggaran 2013

\section{DAFTAR PUSTAKA}

Adesina, A. A., \& Zinnah, M. M. 1993. Technology Characteristics, Farmers' Perceptions and Adoption Decisions: A Tobit Model Application in Sierra Leone. Agricultural Economics, 9, 297-311.

Alisa, Ifa. 2007. Persepsi Petani Terhadap Inovasi Untuk Menggunakan Pupuk Kompos Kotoran Ternak Produk P4S Bumi Lestari Sragen (Kasus Petani di Desa Gondang Kecamatan Gondang Kabupaten Sragen ). Skripsi. Program Studi Sosial Ekonomi Peternakan, Fakultas Peternakan, Institut Pertanian Bogor.

Asmaliyah, Etik Erna Wati H.,Sri Utami, Kusdi Mulyadi, Yudhistira, Fitri Windra Sari. 2010. Pengenalan Tumbuhan Penghasil Pestisida Nabati Dan Pemanfaatannya Secara Tradisional. Editor : Illa Anggraeni. Kementerian Kehutanan Badan Penelitian Dan Pengembangan Kehutanan Pusat Penelitian Dan Pengembangan Produktivitas Hutan. ISBN : 978-602-98588-0-8

Cloyd, R.A. 2004. Natural Indeed: Are Natural Insecticides Safer and Better than Conventional Insecticides?. Illinois Pesticides Review, 17, 3-6.

Dinas Kehutanan dan Perkebunan Kabupaten Sumedang. 2012. Profil Tanaman Tembakau Kabupaten Sumedang.

Oxford Dictionaries .2013. Perception. www.oxforddictionaries.com/ [23/12/1013]

Harwanto, Edhi Martono, Andi Trisyono, Wahyono .2012. Pengaruh Ekstrak Limbah Daun Tembakau Madura Terhadap Aktivitas Makan Larva Spodoptera exigua. Biosaintifika Vol 4, No 1. melalui http://journal.unnes.ac.id/nju/index.php/ biosaintifika [23/12/2013]

Hernanto, F. 1993. Ilmu Usahatani. Penebar Swadaya. Jakarta.

Isman, M.B. 1997. Neem and Other Botanical Insecticides: Barriers to Commercialization. Phytoparasitica 25(4):339-344

Jainuri, M. 2014. Skala Pengukuran. www.academia. edu/5077784/Skala Pengukuran [3/7/2014]

Johnson, D.W. 2006. Vendors of Microbial and Botanical Insecticides and Insect Monitoring 
Devices. Cooperative Extension Service. University of Kentucky, College of Agriculture, Department of Entomology

Kardinan, A. 2000. Pestisida Nabati: Ramuan dan Aplikasi. Penebar Swadaya. Jakarta.

Kardinan,A. 2011. Penggunaan Pestisida Nabati Sebagai Kearifan Lokal Dalam Pengendalian Hama Tanaman Menuju Sistem Pertanian Organik. Pengembangan Inovasi Pertanian 4(4), 2011: 262-278

Mardikanto,T. 1993. Penyuluhan Pembangunan Pertanian. UNS Press. Surakarta.

Mulyana, Deddy. 2004. Ilmu Komunikasi, Suatu Pengantar. PT Remaja Rosdakarya.

Nazir, M. 1988. Metode Penelitian. Ghalia Indonesia, Jakarta

Prabayanti, Herning. 2010. Faktor-Faktor Yang Mempengaruhi Adopsi Biopestisida Oleh Petani Di Kecamatan Mojogedang Kabupaten Karanganyar. Skripsi. Fakultas Pertanian Universitas Sebelas Maret Surakarta. eprints.uns. ac.id/222/1/169931211201010071.pdf

Rogers, E. MandF.F Shoemaker. 1971. Communication of Innovations: A Cross-Cultural Approach, New York: The Free Press

Rogers, E.M 1995. Diffusion of Innovations 4th Edition. New York, USA: The Free Press.
Rudiyanti, Siti. 2010. Toksisitas Ekstrak Daun Tembakau (Nicotina Tobacum) Terhadap Pertumbuhan Ikan Nila Toxicity Of Extract Tobacco Leaves To The Growth Of Oreochromis Niloticus . Jurnal Saintek Perikanan Vol. 6, No. 1, 2010, 56 - 61. Ejournal.Undip.Ac.Id/Index.Php. [31/12/2013]

Samsudin, U. S. 1982. Dasar-Dasar Penyuluhan dan Modernisasi Pertanian. Binacipta. Bandung.

Samsudin. 2008. Pestisida Sintetis dan Bahayanya Bagi Kesehatan Manusia dan Lingkungan. www. pertaniansehat.or.id. [31/12/2013]

Sastrosiswojo, S. 2002. Kajian Sosial Ekonomi dan Budaya Penggunaan Biopestisida di Indonesia. Makalah pada Lokakarya Keanekaragaman Hayati untuk Perlindungan Tanaman, Yogyakarta, Tanggal 7 Agustus 2002.

Schmutterer H. 1995. The Neem Tree Azadirachta indica A. Juss. And Other Meliaceous Plants: Sources of Unique Natural Products for Integrated Pest Management, Medicine, Industry and Other Purposes. Weinheim: VCH.

Susanti, Lulus Dan Hasan Boesri. 2012. Toksisitas Biolarvasida Ekstrak Tembakau Dibandingkan Dengan Ekstrak Zodia Terhadap Jentik Vektor Demam Berdarah Dengue (Aedes Aegypti). Bul. Penelit. Kesehatan, Vol. 40, No. 2, Juni, 2012: 75 - 84

Suwahyono, U. 2010. Cara Membuat dan Petunjuk Penggunaan Pestisida nabati. Penebar Swadaya. Jakarta. 
Sosiohumaniora, Volume 16 No. 2 Juli 2014: 184 - 192

\title{
PERSEPSI PETANI TERHADAP INOVASI TEKNOLOGI PESTISIDA NABATI LIMBAH TEMBAKAU (Suatu Kasus pada Petani Tembakau di Kabupaten Sumedang)
}

\author{
Pingkan Aditiawati ${ }^{1)}$, Mia Rosmiati ${ }^{2)}$, dan Dadang Sumardi ${ }^{3)}$ \\ 1) Bioteknologi Mikroba SITH- ITB, \\ 2) Manajemen Sumberdaya Hayati SITH - ITB \\ 3) Genetika dan Bioteknologi Molekuler SITH - ITB \\ E-mail : pingkan@sith.itb.ac.id
}

\begin{abstract}
Abstrak. Sebagai suatu inovasi, proses adopsi pestisida nabati limbah tembakau membutuhkan suatu proses pemahaman (persepsi) oleh para petani. Suatu inovasi akan diadopsi oleh petani jika mereka mempunyai persepsi yang baik terhadap inovasi tersebut. Oleh karena itu, tujuan penelitian ini akan mengkaji bagaimana persepsi petani terhadap teknologi pestisida nabati limbah tembakau. Penelitian ini dilaksanakan di daerah sentra pengolahan tembakau di Kabupaten Sumedang yaitu di Kecamatan Sukasari dan Tanjungsari. Metode yang digunakan pada penelitian ini adalah metode deskriptif. Penentuan responden dilakukan secara sensus terhadap petani yang mengikuti pelatihan teknologi pestisida nabati limbah tembakau (40 responden). Persepsi petani terhadap inovasi teknologi pestisida nabati limbah tembakau dilihat dari indikator sifat inovasi yaitu relative advantage, compatibility, complexity, triability, dan observability, kemudian diukur dengan menggunakan skala likert. Data tersebut dianalisis dengan menggunakan statistika deskriptif. Hasil penelitian menunjukkan bahwa persepsi petani terhadap inovasi teknologi pestisida nabati limbah tembakau termasuk kriteria positif. Jika petani mempunyai persepsi yang baik diharapkan proses adopsi inovasi pestisida nabati limbah tembakau oleh petani dapat berjalan secara cepat.
\end{abstract}

Kata Kunci : inovasi teknologi, persepsi, pestisida nabati, sifat inovasi

\section{FARMER PERCEPTIONS OF TECHNOLOGY INNOVATION OF BOTANICAL PESTICIDE FROM TOBACCO WASTE}

(A Case on Tobacco Farmers in Sumedang District)

\begin{abstract}
As an innovation, botanical pesticide with active ingredients from tobacco waste product requires a perceptual processes to be adopted by the farmers. An innovation will be adopted by farmers if they have a good perception of the innovation. Therefore, the purpose of this study will examine how perceptions of farmers on botanical pesticide technology from tobacco waste product. This research was conducted in the area of tobacco processing centers in Sumedang. The method used in this research is descriptive method. Determination of respondents conducted a census of all farmers who attended training about botanical pesticide technology with active ingredients from tobacco waste product (40 respondents). Farmer's perception on technological innovation botanical pesticide seen of indicators characteristic of innovation are relative advantage, compatibility, complexity, triability, and observability, then measured using a Likert scale. The data were analyzed using descriptive statistics. The results showed that the perception of farmers towards technological innovation showed positive perception. With a positive perception of the farmer, the adoption of innovation of the botanical pesticide technology from tobacco waste product can occur rapidly.
\end{abstract}

Keywords : technological innovation, perception, botanical pesticide, characteristics of innovation.

\section{PENDAHULUAN}

Tanaman tembakau merupakan salah satu komoditas perkebunan berumur pendek atau musiman yang banyak diusahakan oleh petani dan menjadi komoditas unggulan di Kabupaten Sumedang. Luas tanaman tembakau di Kabupaten Sumedang pada tahun 2011 tercatat seluas 2.496 ha dengan produksi hasil olahan sebanyak 2.260 ton tembakau rajangan kering dengan rata-rata produksi 0,91 ton/ha, yang melibatkan petani sebanyak 9.465 orang. Sentra pengolahan tembakau di Kabupaten Sumedang adalah Kecamatan Sukasari dan Tanjungsari. Minat petani untuk mengembangkan tembakau pada saat ini sangat besar mengingat dalam melaksanakan usahanya cepat memberikan hasil, adanya fasilitas pasar agribisnis tembakau Tanjungsari dan harga jualnya menarik, harga jual pada tahun 2011 rata-rata Rp 30.000,00 s.d. 75.000,00/kg tembakau rajangan kering (Dinas Kehutanan dan Perkebunan Kabupaten Sumedang, 2012).
Kegiatan pengolahan tembakau menjadi tembakau rajangan kering dilaksanakan sepanjang tahun, karena tersedianya bahan baku daun tembakau. Selain dari daerah Sumedang, sumber bahan baku (daun tembakau basah) diperoleh dari daerah-daerah penghasil tembakau di wilayah Jawa Barat seperti Kabupaten Majalengka, Garut, Ciamis (Banjar), Kabupaten Bandung dan sebagainya. Jumlah bahan baku tembakau basah yang diolah/dirajang menjadi tembakau iris halus rata-rata $65 \mathrm{~kg} /$ hari/anggota kelompok. Dari $65 \mathrm{~kg}$ daun basah tembakau dihasilkan limbah berupa batang daun (pakang) sebanyak $15-20 \mathrm{~kg}$. Pada saat ini limbah tersebut belum dimanfaatkan secara optimal. Batang daun/pakang tembakau tersebut biasanya disimpan di pinggir kebun dan setelah busuk dimanfaatkan sebagai pupuk. Padahal, jika limbah tersebut bisa dimanfaatkan secara optimal, maka banyak dampak positif yang ditimbulkan seperti termanfaatkannya potensi sumberdaya lokal (limbah) menjadi bahan yang mempunyai 
nilai ekonomi (nilai tambah), dapat menumbuhkan wirausaha-wirausaha baru di daerah perdesaan dan dapat meningkatkan pendapatan para pengolah tembakau dari produk yang berbahan baku limbah tembakau.

Salah satu upaya yang telah dilakukan untuk memanfaatkan limbah tembakau tersebut adalah dengan pelatihan membuat pestisida nabati yang dilaksanakan oleh Tim Pengabdian Kepada Masyarakat, Sekolah Ilmu dan Teknologi Hayati, ITB. Pestisida nabati limbah tembakau merupakan salah satu jenis pestisida nabati yang ramah lingkungan, aman bagi manusia dan ekosistemnya sehingga dapat mendukung pertanian yang berkelanjutan. Walaupun pestisida nabati lebih unggul dari aspek kesehatan dan lingkungan dibandingkan dengan pestisida kimia, namun sebagai inovasi baru maka dibutuhkan suatu proses pemahaman (persepsi) untuk bisa diadopsi oleh para petani. Adopsi pestisida nabati oleh petani pengolah tembakau di Kabupaten Sumedang sebagai suatu proses hingga akhirnya petani memutuskan untuk mengadopsi atau tidak mengadopsi inovasi tersebut dipengaruhi oleh banyak faktor, misalnya faktor internal dan eksternal. Suatu inovasi akan diadopsi oleh petani jika mereka mempunyai persepsi yang baik terhadap inovasi tersebut. Oleh karena itu, tujuan penelitian ini akan mengkaji bagaimana persepsi petani terhadap teknologi pestisida nabati limbah tembakau.

\section{Persepsi Petani terhadap Inovasi}

Berdasarkan Oxford Dictionaries (2013) persepsi adalah kemampuan untuk melihat, mendengar, atau mengetahui sesuatu melalui indera. Mulyana (2004) menyatakan bahwa persepsi menyangkut kognisi yang mencakup kegiatan mental (otak), penafsiran objek, tanda, orang serta pengalaman yang bersangkutan. Adesina and Zinnah (1993) menyatakan bahwa persepsi adopter terhadap inovasi teknologi mempengaruhi proses adopsi inovasi teknologi yang diusulkan. Jika persepsi adopter positif, maka inovasi teknologi tersebut cenderung lebih cepat diadopsi.

Rogers dan Shoemaker (1971) mengartikan inovasi sebagai gagasan, tindakan atau barang yang dianggap baru oleh seseorang. Tidak menjadi soal, sejauh dihubungkan dengan tingkah laku manusia, apakah ide itu betul-betul baru atau tidak jika diukur dengan selang waktu sejak dipergunakan atau diketemukannya pertama kali. Kebaruan inovasi itu diukur secara subyektif, menurut pandangan individu yang menangkapnya. Mardikanto (1993), mendefinisikan inovasi adalah sesuatu ide, perilaku, produk, informasi, dan praktek-praktek baru yang belum banyak diketahui, diterima dan digunakan/ diterapkan, dilaksanakan oleh sebagian besar warga masyarakat dalam suatu lokalitas tertentu, yang dapat digunakan atau mendorong terjadinya perubahan-perubahan di segala aspek kehidupan masyarakat demi selalu terwujudnya perbaikan-perbaikan mutu hidup setiap individu dan seluruh warga masyarakat yang bersangkutan.
Selanjutnya Mardikanto (1993) mendefinisikan adopsi sebagai proses perubahan perilaku yang berupa pengetahuan (cognitive), sikap (afective) maupun keterampilan (pikomotorik) pada diri seseorang setelah menerima pesan yang disampaikan penyuluh pada sasaranya. Menurut Rogers (1995), keputusan individu untuk mengadopsi suatu inovasi tidak langsung tetapi mengikuti proses yang terdiri dari urutan tindakan dan keputusan yang terjadi dari waktu ke waktu.

Seseorang menerima suatu hal atau ide baru selalu melalui tahapan-tahapan. Samsudin (1982) dan Mardikanto (1993), menjelaskan bahwa tahapan proses adopsi adalah:

1) Tahap kesadaran. Petani mulai sadar tentang adanya sesuatu yang baru, mulai terbuka akan perkembangan dunia luarnya, sadar apa yang sudah ada dan apa yang belum.

2) Tahap minat. Tahap ini ditandai oleh adanya kegiatan mencari keterangan-keterangan tentang hal-hal yang baru diketahuinya.

3) Tahap penilaian. Setelah keterangan yang diperlukan diperoleh, mulai timbul rasa menimbang-nimbang untuk kemungkinan melaksanakannya sendiri.

4) Tahap mencoba. Jika keterangan sudah lengkap, minat untuk meniru besar, dan jika ternyata hasil penilaiannya positif, maka dimulai usaha mencoba hal baru yang sudah diketahuinya.

5) Tahap adopsi. Petani sudah mulai mempraktekkan hal-hal baru dengan keyakinan akan berhasil.

Sedangkan Rogers (1995) menyatakan tahapan proses adopsi inovasi sebagai berikut:

1) Tahap munculnya pengetahuan (Knowledge), dimana seseorang mengetahui adanya inovasi dan memperoleh beberapa pengertian tentang bagaimana inovasi itu berfungsi.

2) Tahap persuasi (Persuasion), dimana seseorang membentuk sikap berkenan atau tidak berkenan terhadap inovasi. Dasar dari proses pengetahuan dan persuasi tersebut identik dengan persepsi.

3) Tahap keputusan (Decisions), dimana seseorang terlibat dalam kegiatan yang membawanya pada pemilihan untuk menerima atau menolak inovasi.

4) Tahapan Implementasi (Implementation), dimana seseorang menetapkan penggunaan inovasi. Penemuan kembali (re-invention) sangat mungkin terjadi pada tahap pelaksanaan.

5) Tahapan Konfirmasi (Confirmation), dimana seseorang mencari penguatan bagi keputusan inovasi yang telah dibuatnya. Pada tahap ini mungkin terjadi seseorang merubah keputusannya jika ia memperoleh informasi yang bertentangan.

Pengambilan keputusan untuk mengadopsi suatu inovasi dipengaruhi oleh beberapa faktor. Rogers dan Shoemaker (1971) menyatakan bahwa keputusan menolak atau menerima inovasi teknologi ditentukan oleh faktor-faktor sosial dan ekonomi petani itu sendiri. Menurut Mardikanto (1993), kecepatan adopsi dipengaruhi oleh banyak faktor, yaitu: (a) sifat 
inovasinya sendiri, baik sifat intrinsik (yang melekat pada inovasinya sendiri) maupun sifat ekstrinsik (menurut atau dipengaruhi oleh keadaan lingkungan), (b) sifat sasarannya, (c) cara pengambilan keputusan, (d) saluran komunikasi yang digunakan, (e) keadaan penyuluh. Berkaitan dengan kemampuan penyuluh untuk berkomunikasi, perlu juga diperhatikan kemampuan berempati atau kemampuan untuk merasakan keadaan yang sedang dialami atau perasaan orang lain, (f) ragam sumber informasi.

Tingkat adopsi dari suatu inovasi tergantung pada persepsi adopter tentang karakteristik inovasi tek nologi tersebut (Rogers, 1995). Ada lima karakteristik yang mendukung penjelasan tingkat adopsi dari suatu inovasi yaitu:

1) Keuntungan-keuntungan relatif (relatif advantages); yaitu sejauhmana suatu inovasi dianggap lebih baik daripada inovasi sebelumnya. Keuntungan relatif ini meliputi tingkat profitabilitas ekonomi, biaya yang rendah, rasa nyaman, penghematan waktu dan usaha serta insentif.

2) Kesesuaian (compatibility); yaitu apakah inovasi mempunyai sifat lebih sesuai dengan nilai yang ada, pengalaman sebelumnya, dan kebutuhan yang diperlukan penerima/adopter.

3) Kerumitan (complexity); yakni apakah inovasi tersebut dirasakan rumit untuk dipahami dan digunakan.

4) Dapat dicobakan (triability); yaitu suatu inovasi akan mudah diterima apabila dapat dicobakan dalam ukuran kecil.

5) Dapat dilihat (observability); yaitu suatu inovasi dapat disaksikan dengan mata. Semakin mudah bagi individu untuk melihat hasil sebuah inovasi, semakin besar kemungkinan mereka untuk mengadopsi.

Beberapa hasil penelitian menunjukkan bahwa persepsi adopter tentang sifat/karakteristik inovasi dapat mempengaruhi tingkat adopsi dari suatu inovasi. Seperti penelitian Alisa (2007) menunjukkan bahwa inovasi untuk menggunakan pupuk kompos kotoran ternak dipersepsikan petani sebagai inovasi yang memiliki sifat memberikan keuntungan relatif, kesesuaian, kerumitan, kemudahan dapat dicoba dan diamati. Kemudian Prabayanti (2010) meneliti tentang faktor-faktor yang mempengaruhi adopsi biopestisida oleh petani di Kecamatan Mojogedang Kabupaten Karanganyar. Hasil penelitian tersebut menyimpulkan bahwa semakin baik persepsi terhadap sifat inovasi maka peluang inovasi tersebut untuk diadopsi semakin tinggi pula.

\section{Pestisida Nabati}

Pestisida nabati merupakan produk alam dari tumbuhan seperti daun, bunga, buah, biji, kulit, dan batang yang mempunyai kelompok metabolit sekunder atau senyawa bioaktif. Tumbuhan mengandung banyak bahan kimia yang merupakan metabolit sekunder dan digunakan oleh tumbuhan sebagai alat pertahanan dari serangan organisme pengganggu. Tumbuhan sebenarnya kaya akan bahan bioaktif, walaupun han- ya sekitar 10.000 jenis produksi metabolit sekunder yang telah teridentifikasi, tetapi sesungguhnya jumlah bahan kimia pada tumbuhan dapat melampaui 400.000 jenis (Asmaliyah, dkk, 2010). Selanjutnya menurut Grainge et al., 1984 dalam Sastrosiswojo (2002), ada 1800 jenis tanaman yang mengandung pestisida nabati yang dapat digunakan untuk pengendalian hama. Di Indonesia, sebenarnya sangat banyak jenis tumbuhan penghasil pestisida nabati, dan diperkirakan ada sekitar 2400 jenis tanaman yang termasuk ke dalam 235 famili (Kardinan, 2000). Pemanfaatan tumbuhan penghasil pestisida nabati dalam pengendalian hama sudah banyak dilakukan, terutama di bidang pertanian dan perkebunan dan hasilnya efektif. Penggunaan suatu pestisida nabati akan lebih baik hasilnya atau lebih efektif apabila dipadukan dengan pestisida nabati lainnya. Aplikasinya dapat dilakukan secara pencampuran atau secara berselang-seling, misal ekstrak daun sirsak dan ekstrak biji mimba. Penggunaan pestisida nabati juga dapat dipadukan dengan musuh alami bila bahan pestisida nabati tersebut tidak beracun bagi musuh alami (Asmaliyah, dkk, 2010).

Salah satu jenis tanaman yang dapat dimanfaatkan sebagai pestisida nabati adalah tembakau. Bagian tembakau yang dapat dimanfaatkan untuk pestisida nabati yaitu batang dan daun. Selain tembakau, tanaman yang dimanfaatkan untuk pestisida nabati di antaranya mimba,daun sirsak, biji srikaya, mahoni, kecubung, mindi, brotowali, biji bengkuang, sambiloto, dan lain-lain.

Beberapa hasil penelitian pemanfaatan ekstrak nabati yang mengandung senyawa bioaktif selain berpengaruh pada aktivitas makan juga berpengaruh terhadap penghambatan aktivitas peneluran, perkembangan telur, larva, dewasa, penghambat pembentukan khitin, kematian, dan mengganggu sistem reproduksi (Isman 1995; Schmutterer 1995). Hasil penelitian Rudiyanti (2010) tentang toksisitas ekstrak daun tembakau (nicotina tobacum) terhadap pertumbuhan ikan nila, menyimpulkan bahwa ekstrak daun tembakau termasuk pestisida alami yang mempunyai daya racun sedang. Pemberian ekstrak daun tembakau pada konsentrasi subletal berpengaruh terhadap pertumbuhan biomassa mutlak dan laju pertumbuhan harian benih ikan nila. Selanjutnya hasil pengujian Harwanto, dkk (2012) tentang pengaruh ekstrak limbah daun tembakau Madura terhadap aktivitas makan larva Spodoptera exigua, menunjukkan bahwa ekstrak limbah daun tembakau Madura berpengaruh negatif terhadap aktivitas makan larva instar III $S$. exigua yang ditunjukkan oleh rendahnya bobot daun yang dikonsumsi dan persentase hambatan makannya semakin tinggi.

Keuntungan menggunakan pestisida nabati dibandingkan pestisida kimia antara lain meminimalkan terjadinya kerusakan lingkungan hidup, tidak membahayakan makhluk lain yang bukan sasaran, seperti predator, parasitoid, serangga penyerbuk, dan serangga berguna lebah madu (Trubus, 2009 dalam Prabayanti, 2010). Selanjutnya Suwahyono (2010) 
menyatakan bahwa pestisida nabati sangat bermanfaat baik dari aspek sosial ekonomi maupun aspek lingkungan. Ditinjau dari aspek sosial ekonomi, pestisida nabati merupakan salah satu faktor yang menentukan dalam upaya menurunkan biaya produksi sehingga secara tidak langsung dapat meningkatkan pendapatan petani. Ditinjau dari aspek lingkungan, pestisida nabati dapat mengurangi dampak negatif dari penggunaan pestisida kimia seperti terjadinya degradasi lingkungan, adanya residu bahan kimia didalam tanah dan terakumulasi di dalam jaringan tanaman dan tetap bertahan sampai dikonsumsi oleh manusia maupun hewan serta menurunnya biota tanah.

\section{METODE}

Penelitian ini dilakukan di Kelompok tani Gunasari 2, Desa Sukasari Kecamatan Sukasari dan Kelompok tani Mekarjaya di Desa Pasigaran Kecamatan Tanjungsari Kabupaten Sumedang pada bulan Agustus sampai Oktober 2013. Pemilihan lokasi dilakukan secara sengaja (purposive) dengan pertimbangan bahwa kedua kelompok tersebut merupakan kelompok tani yang secara terus menerus mengolah tembakau menjadi tembakau iris/kering, sehingga bahan baku untuk pembuatan pestisida nabati limbah tembakau selalu tersedia, dan anggota kelompok tani di kedua kelompok tersebut telah mendapat pelatihan pemanfaatan limbah tembakau menjadi pestisida nabati yang dilaksanakan oleh Tim Pengabdian Kepada Masyarakat, Sekolah Ilmu dan Teknologi Hayati, Institut Teknologi Bandung.

Metode yang digunakan dalam penelitian ini adalah metode deskriptif. Metode deskriptif yaitu pencarian fakta dengan interpretasi yang tepat. Penelitian deskriptif mempelajari masalah-masalah dalam masyarakat, tata cara yang berlaku dalam masyarakat serta situasi-situasi tertentu, termasuk tentang hubungan, kegiatan-kegiatan, sikap-sikap, pandangan-pandangan, serta proses-proses yang sedang berlangsung dan pengaruh-pengaruh dari suatu fenomena. Teknik penelitian yang digunakan adalah teknik studi kasus, yaitu penelitian tentang status subjek penelitian (individu, kelompok, lembaga, masyarakat) yang berkenaan dengan suatu fase spesifik atau khas dari keseluruhan personalitas (Nazir, 1988).

Penentuan responden dilakukan secara sensus terhadap seluruh anggota kedua kelompok tersebut yang mengikuti pelatihan teknologi pestisida nabati limbah tembakau yaitu Kelompok tani Gunasari 2 sebanyak 20 orang dan Kelompok tani Mekarjaya sebanyak 20 orang.

Data yang digunakan adalah data primer yang diambil dengan menggunakan kuesioner. Data primer meliputi karakteristik petani dan persepsi petani terhadap inovasi teknologi pestisida nabati limbah tembakau. Persepsi petani terhadap inovasi teknologi pestisida nabati limbah tembakau diukur dengan menggunakan skala likert dengan skor 1 (sangat tidak setuju), skor 2 (tidak setuju), skor 3 (ragu-ragu), skor 4 (setuju) dan skor 5 (sangat setuju), kemudian data tersebut dianalisis dengan menghitung:

a. Skor maksimal yaitu skor jawaban terbesar dikali banyaknya item/indikator

b. Skor minimum yaitu skor jawaban terkecil dikali banyaknya item/indikator

c. Nilai median (Me)yaitu hasil penjumlahan skor maksimum dengan skor minimum dibagi 2

d. Nilai kuartil ke satu (K1) yaitu hasil penjumlahan skor minimum dengan nilai median dibagi 2

e. Nilai kuartil ke tiga (K3) yaitu hasil penjumlahan skor maksimum dengan median dibagi 2

Berdasarkan perhitungan tersebut, maka persepsi petani terhadap inovasi teknologi pestisida nabati limbah tembakau dikategorikan sebagai berikut:

a. Sangat positif : $\mathrm{K} 3 \leq \mathrm{X} \leq$ skor maks

b. Positif : $\mathrm{Me} \leq \mathrm{X}<\mathrm{K} 3$

c. Negatif: $\mathrm{K} 1 \leq \mathrm{X}<\mathrm{Me}$

d. Sangat negatif : Skor $\min \leq \mathrm{X}<\mathrm{K} 1$ (Jainuri,2014)

\section{HASIL DAN PEMBAHASAN}

\section{Karakteristik Responden}

Karakteristik responden dalam penelitian ini meliputi umur, pengalaman berusahai tembakau, luas lahan garapan, pendidikan, status penguasaan lahan dan pendapatan. Tabel 4.1 memperlihatkan bahwa umur produktif petani responden pada umumnya berumur 30 - 55 tahun (60\%). Jika dilihat berdasarkan penggolongan umur produktif dan tidak produktif, maka sebagian besar petani responden berada dalam kategori umur produktif, yang berarti sangat berpeluang dalam upaya peningkatan produktivitas usaha mereka karena umur produktif sangat berpengaruh dengan kemampuan fisik petani untuk bekerja secara optimal.

Pengalaman petani dalam berusaha berpengaruh terhadap cara merespon suatu inovasi. Semakin lama pengalaman berusaha, maka tingkat respon terhadap suatu teknologi akan semakin tinggi. Pengalaman berusaha sangat penting dalam rangka pengelolaan usahatani, baik dalam pengambilan keputusan pemilihan komoditas yang ditanam maupun dalam penggunaan faktor produksi. Kenyataan menunjukkan bahwa semakin berpengalaman petani dalam berusaha, cenderung semakin efisien dalam mengalokasikan faktor produksi dalam usaha tersebut. Proporsi terbesar dari responden adalah petani yang memiliki pengalaman di atas 10 tahun. Hal ini memberikan indikasi bahwa tembakau sejak lama telah diusahakan dan dipilih oleh petani secara terus menerus sebagai salah satu sumber pendapatan.

Pendidikan formal merupakan lama pendidikan yang ditempuh responden pada bangku sekolah. Tingkat pendidikan formal petani sangat berpengaruh terhadap kemampuan dalam merespon suatu inovasi. Makin tinggi tingkat pendidikan formal petani diharapkan makin rasional dalam pola pikir dan juga daya nalarnya. Dengan pendidikan yang semakin tinggi diharapkan dapat lebih mudah merubah sikap dan perilaku untuk bertindak lebih rasional. Sebagian besar petani responden telah menempuh pendidikan formal walaupun masih tergolong pada 
Tabel 1. Karakteristik Responden

\begin{tabular}{|c|c|c|c|}
\hline$\overline{\text { No }}$ & Karakteristik & Jumlah & $\%$ \\
\hline \multirow[t]{4}{*}{$\overline{1}$} & Umur (tahun) & & \\
\hline & $\leq 30$ & 10 & 25 \\
\hline & $30-55$ & 24 & 60 \\
\hline & $>55$ & 6 & 15 \\
\hline \multirow[t]{4}{*}{2} & Pengalaman mengusahakan/mengolah tembakau: (tahun) & & \\
\hline & $\leq 10$ & 5 & 13 \\
\hline & $10-20$ & 15 & 38 \\
\hline & $>20$ & 20 & 50 \\
\hline \multirow[t]{4}{*}{3} & Luas pengusahaan tembakau: (ha) & & \\
\hline & $\leq 0,5$ & 19 & 48 \\
\hline & $0,51-1,0$ & 14 & 35 \\
\hline & $>1,0$ & 7 & 18 \\
\hline \multirow[t]{5}{*}{4} & Pendidikan : & & \\
\hline & Tidak tamat SD & 10 & 25 \\
\hline & $\mathrm{SD}$ & 15 & 38 \\
\hline & SMP & 9 & 23 \\
\hline & SMA & 6 & 15 \\
\hline \multirow[t]{4}{*}{5.} & Status Penguasaan Lahan: & & \\
\hline & Pemilik & 10 & 25 \\
\hline & Penyewa & 24 & 60 \\
\hline & Gadai & 6 & 15 \\
\hline \multirow[t]{4}{*}{6.} & Pendapatan / bulan & & \\
\hline & $<1.5000 .000$ & 5 & 13 \\
\hline & $1.500 .000-3.000 .000$ & 25 & 63 \\
\hline & $>3.000 .000$ & 10 & 25 \\
\hline
\end{tabular}

tingkat pendidikan SD, sehingga dapat dikatakan sumberdaya manusia (SDM) petani masih tergolong rendah, sebab tingkat pendidikan seseorang menentukan keberhasilan dalam mengelolah usahataninya.

Luas penguasaan lahan merupakan keseluruhan luas lahan yang diusahakan petani responden baik milik sendiri, menyewa, maupun gadai. Luas penguasaan lahan akan berpengaruh terhadap adopsi inovasi. Hal ini disebabkan karena luas penguasaan lahan akan mempengaruhi banyaknya pendapatan yang diterima oleh petani. Semakin luas penguasaan lahan yang digunakan untuk kegiatan usahatani maka akan semakin tinggi pula hasil produksinya. Hernanto (1993) menyebutkan, luas lahan usahatani menentukan pendapatan, taraf hidup dan derajat kesejahteraan rumah tangga tani. Hal tersebut tentunya akan turut meningkatkan pendapatan usahatani sehingga meningkatkan adopsi terhadap suatu inovasi.

Responden mempunyai lahan luas dan sedang $(52,50 \%)$ serta sempit $(47,50 \%)$. Hal tersebut akan berpengaruh terhadap adopsi inovasi pestisida nabati. Pada umumnya petani yang memiliki lahan sempit cenderung kurang berani mencoba suatu inovasi karena takut gagal. Lain halnya dengan petani yang memiliki lahan luas, mereka cenderung berani mencoba inovasi pada sebagian kecil lahannya tanpa takut gagal karena masih memiliki sebagian besar luas lahannya yang tidak dicobakan suatu inovasi. Status penguasaan lahan yang digunakan untuk usahatani tembakau didominasi oleh status sewa.

Pendapatan merupakan pendapatan total yang diperoleh responden baik dari kegiatan usahatani dan pengolahan tembakau maupun luar usahatani. Petani dengan pendapatan yang tinggi akan cenderung lebih cepat untuk menerima dan menerapkan suatu inovasi karena seseorang dengan pendapatan tinggi cenderung lebih berani mencoba hal-hal baru yang ada di sekitar mereka. Selain pendapatan dari usahatani tembakau dan pengolahan daun tembakau, sebagian petani juga memperoleh pendapatan dari usahatani padi, singkong, ubi jalar, pisang, dan sayuran serta pendapatan dari luar usahatani tersebut seperti menjadi buruh tani, tukang ojeg, pegawai negeri dan pedagang.

\section{Persepsi Petani terhadap Inovasi Teknologi Pestisida Nabati Limbah Tembakau}

Persepsi petani terhadap inovasi teknologi pestisida nabati limbah tembakau diukur dari persepsi petani terhadap sifat/karakteristik inovasi tersebut yaitu persepsi terhadap relative advantage (keuntungan relatif), compatibility (kesesuaian), complexity (kerumitan), triability (ketercobaan), dan observability (keteramatan). Untuk lebih jelasnya dapat diuraikan sebagai berikut:

\section{Persepsi terhadap Relative Advantage (Keuntungan Relatif) Pestisida Nabati Limbah Tembakau}

Salah satu pertimbangan petani untuk mengadopsi suatu inovasi adalah apabila inovasi tersebut menguntungkan bagi calon adopternya. Persepsi petani terhadap keuntungan relatif pestisida nabati dapat dilihat dari dua indikator yaitu biaya pembuatan pestisida nabati limbah tembakau lebih murah daripada pestisida kimia sehingga dapat menghemat biaya produksi dan pestisida nabati lebih unggul dilihat dari aspek keamanan terhadap kesehatan dan

\begin{tabular}{lccc}
\hline $\begin{array}{l}\text { Kategori } \\
\text { persepsi }\end{array}$ & $\begin{array}{c}\text { Kategori } \\
\text { Skor }\end{array}$ & $\begin{array}{c}\text { Jumlah } \\
\text { Responden }\end{array}$ & $\begin{array}{c}\text { Persen } \\
(\%)\end{array}$ \\
\hline Sangat & $8-10$ & 2 & 5 \\
positif & & & \\
Positif & $6-8$ & 32 & 80 \\
Negatif & $4-6$ & 6 & 15 \\
Sangat & $2-4$ & 0 & 0 \\
Negatif & & &
\end{tabular}

lingkungan dibandingkan pestisida kimia. Persepsi responden terhadap keuntungan relatif pestisida nabati dapat dilihat pada Tabel 2 .

Tabel 2. Persepsi Petani terhadap Keuntungan Relatif Inovasi Pestisida Nabati Limbah Tembakau

Berdasarkan Tabel 2 dapat dilihat bahwa persepsi petani terhadap keuntungan relatif inovasi pestisida nabati sebagian besar positif (80\%). Petani menilai bahwa biaya pembuatan pestisida nabati tergolong murah dibandingkan dengan biaya pembelian pestisida kimia yang semakin mahal. Oleh sebab itu, penggunaan pestisida nabati menjadi solusi bagi petani dalam menghadapi masalah keterbatasan modal untuk pembelian pestisida kimia. Rendahnya biaya produksi untuk membuat pestisida nabati disebabkan bahan-bahan untuk pembuatan pestisida nabati tersebut berasal dari limbah tembakau (batang dan sisa-sisa daun tembakau) yang selama ini tidak dimanfaatkan secara optimal. Selain limbah tembakau, bahan-bahan lainnya yang digunakan untuk campuran pembuatan pestisida nabati banyak tersedia di lingkungan sekitar seperti daun sirsak, daun mindi, kecubung, nimba dsb. Selain ketersediaannya cukup banyak, tanaman-tanaman tersebut sudah dikenal oleh petani di daerah penelitian. Suwahyono (2010) dan Prabayanti (2010) berpendapat bahwa rendahnya biaya pembuatan pestisida nabati tersebut 
menyebabkan biaya usahatani lebih rendah sehingga keuntungan yang diperoleh petani menjadi lebih tinggi.

Petani menilai pestisida nabati ini juga lebih ung gul dibandingkan dengan pestisida kimia dalam aspek keamanan bagi kesehatan dan lingkungan serta efektifitas dalam membasmi hama karena kandungan bahan-bahan aktif yang ada pada bahan baku pestisida nabati tersebut bersifat racun bagi hama tanaman walaupun jarang menyebabkan kematian. Pestisida nabati juga tidak membunuh hewan-hewan yang bukan termasuk golongan hama tanaman (Kardinan, 2000). Hal tersebut tentunya dapat mengurangi kerugian kehilangan hasil panen akibat serangan hama maupun penyakit tanaman. Selain itu, hasil penelitian Prabayanti (2010) menyebutkan bahwa inovasi biopestisida yang ramah lingkungan dapat membantu pemenuhan kebutuhan pangan yang sehat dan terhindar dari zat-zat beracun karena residu penggunaan biopestisida cepat hilang.

\section{Persepsi Petani terhadap Compatibility (Kese- suaian) Pestisida Nabati Limbah Tembakau}

Pada penelitian ini, persepsi petani terhadap kesesuaian pestisida nabati limbah tembakau dilihat dari kesesuaian inovasi pestisida nabati limbah tembakau dengan kondisi dan kebiasaan masyarakat

(petani) setempat, kebutuhan petani, dan keadaan lingkungan. Persepsi responden terhadap kesesuaian

\begin{tabular}{lccc}
\hline $\begin{array}{c}\text { Kategori } \\
\text { persepsi }\end{array}$ & $\begin{array}{c}\text { Kategori } \\
\text { Skor }\end{array}$ & $\begin{array}{c}\text { Jumlah } \\
\text { Responden }\end{array}$ & $\begin{array}{c}\text { Persen } \\
(\%)\end{array}$ \\
\hline Sangat & $12-15$ & 13 & 32,5 \\
positif & & & 57,5 \\
Positif & $9-12$ & 23 & 10 \\
Negatif & $6-9$ & 4 & 0 \\
Sangat & $3-6$ & 0 & \\
Negatif & & & \\
pestisida nabati dapat dilihat pada Tabel 3. \\
Tabel 3. Persepsi Petani terhadap Kesesuaian Inovasi Pestisida \\
\multicolumn{4}{c}{ Nabati Limbah Tembakau }
\end{tabular}

Berdasarkan Tabel 3 dapat diketahui bahwa petani responden menilai positif (57.5\%) dan 32,5\% menilai sangat positif terhadap inovasi pestisida nabati. Pestisida nabati memiliki kesesuaian yang baik dengan kondisi dan kebiasaan masyarakat setempat dimana pestisida nabati dapat dibuat sendiri oleh petani dan bahan baku untuk membuat pestisida nabati tersebut sudah dikenal dan tersedia di wilayah sekitarnya sehingga tidak membutuhkan biaya yang banyak. Selain itu, penggunaannya juga tidak merubah kebiasaan petani dalam menggunakan alat semprot karena pestisida nabati dapat diaplikasikan dengan menggunakan alat semprot (sprayer) gendong seperti pestisida kimia pada umumnya.

Kesesuaian dengan kebutuhan petani yaitu saat ini sebagian besar petani sudah menyadari dan merasakan dampak negatif pemakaian pestisida kimia yang terus menerus sehingga mereka membutuhkan inovasi untuk mengendalikan organisme pengganggu tanaman (OPT) yang ramah lingkungan. Walaupun petani menganggap kecepatan pengendalian pestisida nabati tersebut tidak secepat pestisida kimia, namun para petani sudah menyadari bahwa penggunaan pestisida kimia berpengaruh tidak baik terhadap kesehatan dan lingkungan. Selain itu, ketersediaan pestisida kimia di tingkat lokal (desa) kadang-kadang sulit diperoleh dan harganya mahal.

Kesesuaian dengan kondisi lingkungan yaitu masyarakat (petani) tidak merasa khawatir dengan dampak yang ditimbulkan apabila menggunakan pestisida nabati, karena mereka merasa yakin bahwa pestisida nabati tidak akan merusak lingkungan. Beberapa hasil penelitian sebelumnya menyimpulkan bahwa pada saat ini penggunaan pestisida kimia yang berlebihan menyebabkan pencemaran lingkungan, sedangkan residu dari penggunaan pestisida nabati segera hilang sehingga tidak akan berdampak buruk bagi lingkungan baik udara, tanah maupun biota tanah (Prabayanti, 2010; Suwahyono, 2010). Menurut Kardinan (2011), untuk menuju sistem pertanian organik, pestisida nabati merupakan alternatif untuk mengurangi dampak negatif pestisida sintetis.

\section{Persepsi Petani terhadap Complexity (Kerumitan) Pestisida Nabati Limbah Tembakau}

Kerumitan suatu inovasi dapat mempengaruhi cepat tidaknya seseorang mengadopsi inovasinya. Kerumitan pestisida nabati limbah tembakau dapat dilihat melalui persepsi petani terhadap inovasi tersebut yang meliputi sulit tidaknya pemahaman petani dalam membuat dan mengaplikasikan pestisida nabati tersebut. Persepsi responden terhadap kerumitan pestisida nabati dapat dilihat pada Tabel 4 berikut:

\begin{tabular}{lccc}
\hline $\begin{array}{c}\text { Kategori } \\
\text { persepsi }\end{array}$ & Kategori Skor & $\begin{array}{c}\text { Jumlah } \\
\text { Responden }\end{array}$ & Persen (\%) \\
\hline Sangat positif & $8-10$ & 11 & 27,5 \\
Positif & $6-8$ & 26 & 65 \\
Negatif & $4-6$ & 3 & 7,5 \\
Sangat & $2-4$ & 0 & 0 \\
Negatif & & & \\
\hline
\end{tabular}

Tabel 4. Persepsi Petani terhadap Complexity (Kerumitan) Inovasi Pestisida Nabati Limbah Tembakau

Berdasarkan Tabel 4 dapat dilihat bahwa sebagian besar petani $(65 \%)$ menilai positif terhadap tingkat kerumitan inovasi pestisida nabati limbah tembakau, artinya pemahaman petani terhadap pembuatan dan penggunaan (aplikasi) pestisida nabati termasuk tidak rumit (mudah). Cara pembuatannya pun mudah, hal ini dilihat dari aspek ketersediaan bahan baku dan keterampilan petani. Bahan-bahan pembuatan pestisida nabati limbah tembakau sangat mudah diperoleh di sekitar wilayahnya dan bahan-bahan tersebut juga selalu tersedia. Limbah tembakau berupa batang dan sisa-sisa daun dari proses rajangan tersedia cukup banyak di daerah penelitian. Cara pembuatan pestisida nabati limbah tembakau tidak memerlukan keterampilan khusus, namun memerlukan ketelatenan karena proses pembuatannya memerlukan waktu 
yang cukup lama (sekitar 1-2 hari), sehingga ada 3 orang petani $(7,5 \%)$ yang menyatakan bahwa cara pembuatan dan penggunaan pestisida nabati limbah tembakau tersebut tidak praktis.

Penggunaan pestisida nabati tidak menyulitkan petani karena cara penggunaan pestisida nabati tidak jauh berbeda dengan penggunaan pestisida kimia yaitu pestisida nabati limbah tembakau cair dicampur dengan air kemudian disemprotkan ke tanaman dengan menggunakan alat semprot (sprayer).

\section{Persepsi Petani terhadap Triability (Ketercobaan) Pestisida Nabati}

Sebelum suatu inovasi diadopsi oleh petani hendaknya suatu inovasi dapat dicobakan secara terbatas (dalam skala yang lebih kecil). Petani juga akan lebih percaya pada suatu inovasi ketika suatu inovasi dapat dicoba atau mungkin telah dicoba oleh petani lain dan memiliki tingkat keberhasilan. Adapun persepsi petani responden terhadap ketercobaan pestisida nabati adalah sebagai berikut:

\begin{tabular}{lccc}
\hline $\begin{array}{c}\text { Kategori } \\
\text { persepsi }\end{array}$ & $\begin{array}{c}\text { Kategori } \\
\text { Skor }\end{array}$ & $\begin{array}{c}\text { Jumlah } \\
\text { Responden }\end{array}$ & Persen (\%) \\
\hline Sangat positif & $12-15$ & 19 & 47,5 \\
Positif & $9-12$ & 21 & 52,5 \\
Negatif & $6-9$ & 0 & 0 \\
Sangat & $3-6$ & 0 & 0 \\
Negatif & & & \\
\hline
\end{tabular}

Tabel 5. Persepsi Petani terhadap Ketercobaan Inovasi Pestisida Nabati

Berdasarkan Tabel 5 dapat diketahui bahwa sebagian besar petani menilai positif dan sangat positif terhadap ketercobaan pestisida nabati karena petani menilai inovasi pestisida nabati dapat dicoba sebelum benar-benar diadopsi oleh petani. Petani dapat mencoba membuat ramuan pestisida nabati limbah tembakau dengan teknologi yang sangat sederhana (mudah dan murah). Sebelum mengadopsi pestisida nabati limbah tembakau, petani dapat membuat pestisida nabati dalam takaran yang kecil semacam percobaan, kemudian diaplikasikan ke tanaman untuk mengendalikan hama pada lahan yang sempit. Pada penelitian ini, petani membuat pestisida nabati limbah tembakau secara berkelompok yaitu di kelompok tani Gunasari 2 dan kelompok tani Mekarjaya.

Beberapa teknik yang umum digunakan untuk mengolah pestisida nabati diantaranya dengan teknik merendam, mengekstrak dan ataupun merebus bagian batang dan atau daun tembakau. Contoh dengan teknologi sederhana adalah dengan cara mengeringkan batang dan atau sisa-sisa daun tembakau, menumbuk atau menggilingnya menjadi serbuk, kemudian serbuk direndam dalam air selama semalam, disaring dan langsung dapat diaplikasikan ke tanaman yang terserang hama dan atau penyakit.

Pestisida nabati limbah tembakau yang berupa larutan pestisida nabati cair juga dapat digunakan untuk mengendalikan beberapa jenis hama yang menyerang suatu pertanaman. Senyawa yang dikandung tembakau adalah nikotin. Susanti dan Boesri (2012) menyatakan, nikotin selain beracun untuk manusia, tetapi dapat dimanfaatkan juga untuk racun serangga. Nikotin merupakan racun syaraf yang bereaksi cepat. Nikotin berperan sebagai racun kontak bagi serangga seperti ulat perusak daun, aphids, triphs, dan pengendali jamur (fungisida).

\section{Persepsi Petani terhadap Observability (Ketera- matan) Pestisida Nabati Limbah Tembakau}

Keteramatan pestisida nabati di sini dapat dilihat melalui persepsi petani terhadap keunggulan dan kelemahan yang dapat diamati jika menggunakan inovasi teknologi pestisida nabati dan sejauhmana hasil penggunaan pestisida nabati disebarluaskan/dikomunikasikan kepada yang lain. Persepsi responden terhadap keteramatan pestisida nabati dapat dilihat pada Tabel 6.

Berdasarkan Tabel 6. terlihat bahwa sebagian besar petani (70\%) memiliki persepsi positif terhadap keteramatan pestisida nabati. Pestisida nabati sebagai salah satu komponen dalam pengelolaan OPT pertanian memiliki kelebihan dan kelemahan. Berdasarkan hasil wawancara dengan petani, penggunaan pestisida nabati cukup aman untuk kesehatan petani, tidak mencemari lingkungan dan binatang/serangga yang menguntungkan bagi tanaman tidak ikut mati. Namun demikian proses pembuatan pestisida nabati cukup lama, daya racunnya rendah dan cepat hilang sehingga agar pestisida nabati tersebut efektif dalam mengendalikan hama dan penyakit tanaman maka penyemprotannya relatif harus sering.

Berdasarkan hasil penelitian Prabayanti (2010), petani juga dapat merasakan bahwa OPT yang menyerang tanaman mereka dapat efektif dikendalikan setelah menyemprotkan pestisida nabati pada tanaman yang terserang OPT walaupun kecepatan dalam mengendalikan OPT tidak secepat pestisida kimia, dan frekuensi penyemprotan harus berulang-ulang karena sifat pestisida nabati cepat terdegradasi.

\begin{tabular}{lccc}
\hline $\begin{array}{c}\text { Kategori } \\
\text { persepsi }\end{array}$ & Kategori Skor & $\begin{array}{c}\text { Jumlah } \\
\text { Responden }\end{array}$ & Persen (\%) \\
\hline Sangat positif & $8-10$ & 10 & 25 \\
Positif & $6-8$ & 28 & 70 \\
Negatif & $4-6$ & 2 & 5 \\
Sangat & $2-4$ & 0 & 0 \\
Negatif & & &
\end{tabular}

Tabel 6. Persepsi Petani terhadap Keteramatan Inovasi Pestisida Nabati Limbah Tembakau

Temuan penelitian ini mendukung beberapa hasil penelitian sebelumnya yang menyimpulkan bahwa kelebihan pestisida nabati antara lain cepat terdegradasi sehingga tidak meninggalkan residu dalam waktu lama, cara kerjanya cepat, daya racun terhadap binatang mamalia rendah, dan daya racun terhadap tanaman juga rendah (kurang fitotoksik). Sementara itu kekurangannya antara lain karena cepat terdegradasi maka memerlukan frekuensi 
aplikasi lebih sering, kurangnya sumber bahan baku, sulit untuk melakukan pengendalian kualitas dan standarisasi, kurangnya data terhadap berbagai hama dan sulitnya melakukan registrasi (Isman, 1997; Kardinan, 2000; Cloyd, 2004; Johnson, 2006).

Keberhasilan hasil aplikasi pestisida nabati dapat disebarluaskan kepada petani yang lain, baik dalam satu kelompok tani maupun antar kelompok tani, hal ini berkaitan dengan perilaku petani dimana jika ada suatu inovasi, mereka tidak akan cepat mengadopsinya tetapi mereka akan melihat dulu keberhasilannya. Semakin kelihatan atau terbukti keberhasilan suatu inovasi, maka semakin cepat petani mengadopsinya. Seperti pendapat Rogers (1995), keputusan individu untuk mengadopsi suatu inovasi tidak langsung tetapi mengikuti proses yang terdiri dari urutan tindakan dan keputusan yang terjadi dari waktu ke waktu.

\section{SIMPULAN}

Berdasarkan hasil penelitian dapat disimpulkan bahwa sebagian besar persepsi petani terhadap inovasi teknologi pestisida nabati limbah tembakau termasuk kriteria positif. Secara lebih rinci dapat digambarkan persepsi petani mengenai sifat-sifat inovasi teknologi pestisida nabati limbah tembakau yang terdiri atas:

Keuntungan relatif, sebagian besar (80\%) persepsi petani termasuk dalam kategori positif, artinya inovasi pestisida nabati memberikan beberapa keuntungan bagi petani yaitu biaya lebih murah dan lebih unggul daripada pestisida kimia.

Kesesuaian, sebagian besar $(57,5 \%)$ termasuk dalam kategori positif dan 32,5\% termasuk sangat positif artinya inovasi pestisida nabati cukup sesuai dengan kondisi dan kebiasaan masyarakat (petani), kebutuhan petani dan keadaan lingkungan.

Kerumitan, sebagian besar (65\%) termasuk dalam kategori positif dan $27,5 \%$ termasuk sangat positif artinya cara pembuatan pestisida nabati cukup mudah dipahami dan penggunaaannya tidak sulit.

Ketercobaan, sebagian besar (52,5\%) termasuk dalam kategori positif dan $47,5 \%$ sangat positif, artinya inovasi pestisida nabati dapat dicoba oleh petani dalam takaran kecil dan dapat dicoba diaplikasikan pada lahan yang sempit.

Keteramatan, sebagian besar $(70 \%)$ termasuk dalam kategori positif dan $25 \%$ termasuk sangat positif, artinya keunggulan dan kelemahan inovasi pestisida nabati dapat diamati dan hasil pengaplikasian pada tanaman dapat disebarluaskan ke petani lain.

Para petani diharapkan dapat mengaplikasikan pestisida nabati limbah tembakau pada tanamantanaman yang terserang hama karena berdasarkan penelitian-penelitian sebelumnya, pestisida nabati berbahan baku tembakau cukup efektif mengendalikan organisme pengganggu tanaman (OPT). Para petani yang masih ragu-ragu untuk mengaplikasikan pestisida nabati limbah tembakau ini dapat mencoba membuat dalam skala kecil dan mengaplikasikannya pada tanaman atau melihat dulu keberhasilan petani lain (anggota kelompok tani) yang telah menggunakan pestisida nabati limbah tembakau ini.
Perlu dilakukan penelitian lanjutan mengenai efektifitas pestisida nabati limbah tembakau dalam mengendalikan organisme pengganggu tanaman (OPT) pada tanaman pangan, hortikultura, dan perkebunan.

\section{UCAPAN TERIMA KASIH}

Ucapan terima kasih disampaikan kepada DP2M Dikti yang telah memberi dana untuk kegiatan Pengabdian Pada Masyarakat melalui IbM Kelompok Tani Pengolah Tembakau Tahun Anggaran 2013

\section{DAFTAR PUSTAKA}

Adesina, A. A., \& Zinnah, M. M. 1993. Technology Characteristics, Farmers' Perceptions and Adoption Decisions: A Tobit Model Application in Sierra Leone. Agricultural Economics, 9, 297-311.

Alisa, Ifa. 2007. Persepsi Petani Terhadap Inovasi Untuk Menggunakan Pupuk Kompos Kotoran Ternak Produk P4S Bumi Lestari Sragen (Kasus Petani di Desa Gondang Kecamatan Gondang Kabupaten Sragen ). Skripsi. Program Studi Sosial Ekonomi Peternakan, Fakultas Peternakan, Institut Pertanian Bogor.

Asmaliyah, Etik Erna Wati H.,Sri Utami, Kusdi Mulyadi, Yudhistira, Fitri Windra Sari. 2010. Pengenalan Tumbuhan Penghasil Pestisida Nabati Dan Pemanfaatannya Secara Tradisional. Editor : Illa Anggraeni. Kementerian Kehutanan Badan Penelitian Dan Pengembangan Kehutanan Pusat Penelitian Dan Pengembangan Produktivitas Hutan. ISBN : 978-602-98588-0-8

Cloyd, R.A. 2004. Natural Indeed: Are Natural Insecticides Safer and Better than Conventional Insecticides?. Illinois Pesticides Review, 17, 3-6.

Dinas Kehutanan dan Perkebunan Kabupaten Sumedang. 2012. Profil Tanaman Tembakau Kabupaten Sumedang.

Oxford Dictionaries .2013. Perception. www.oxforddictionaries.com/ [23/12/1013]

Harwanto, Edhi Martono, Andi Trisyono, Wahyono .2012. Pengaruh Ekstrak Limbah Daun Tembakau Madura Terhadap Aktivitas Makan Larva Spodoptera exigua. Biosaintifika Vol 4, No 1. melalui http://journal.unnes.ac.id/nju/index.php/ biosaintifika [23/12/2013]

Hernanto, F. 1993. Ilmu Usahatani. Penebar Swadaya. Jakarta.

Isman, M.B. 1997. Neem and Other Botanical Insecticides: Barriers to Commercialization. Phytoparasitica 25(4):339-344

Jainuri, M. 2014. Skala Pengukuran. Www.academia. edu/5077784/Skala Pengukuran [3/7/2014]

Johnson, D.W. 2006. Vendors of Microbial and Botanical Insecticides and Insect Monitoring 
Devices. Cooperative Extension Service. University of Kentucky, College of Agriculture, Department of Entomology

Kardinan, A. 2000. Pestisida Nabati: Ramuan dan Aplikasi. Penebar Swadaya. Jakarta.

Kardinan,A. 2011. Penggunaan Pestisida Nabati Sebagai Kearifan Lokal Dalam Pengendalian Hama Tanaman Menuju Sistem Pertanian Organik. Pengembangan Inovasi Pertanian 4(4), 2011: $262-278$

Mardikanto,T. 1993. Penyuluhan Pembangunan Pertanian. UNS Press. Surakarta.

Mulyana, Deddy. 2004. Ilmu Komunikasi, Suatu Pengantar. PT Remaja Rosdakarya.

Nazir, M. 1988. Metode Penelitian. Ghalia Indonesia, Jakarta

Prabayanti, Herning. 2010. Faktor-Faktor Yang Mempengaruhi Adopsi Biopestisida Oleh Petani Di Kecamatan Mojogedang Kabupaten Karanganyar. Skripsi. Fakultas Pertanian Universitas Sebelas Maret Surakarta. eprints.uns. ac.id/222/1/169931211201010071.pdf

Rogers, E. MandF.F Shoemaker. 1971. Communication of Innovations: A Cross-Cultural Approach, New York: The Free Press

Rogers, E.M 1995. Diffusion of Innovations 4th Edition. New York, USA: The Free Press.
Rudiyanti, Siti. 2010. Toksisitas Ekstrak Daun Tembakau (Nicotina Tobacum) Terhadap Pertumbuhan Ikan Nila Toxicity Of Extract Tobacco Leaves To The Growth Of Oreochromis Niloticus . Jurnal Saintek Perikanan Vol. 6, No. 1, 2010, 56 - 61. Ejournal.Undip.Ac.Id/Index.Php. [31/12/2013]

Samsudin, U. S. 1982. Dasar-Dasar Penyuluhan dan Modernisasi Pertanian. Binacipta. Bandung.

Samsudin. 2008. Pestisida Sintetis dan Bahayanya Bagi Kesehatan Manusia dan Lingkungan. www. pertaniansehat.or.id. [31/12/2013]

Sastrosiswojo, S. 2002. Kajian Sosial Ekonomi dan Budaya Penggunaan Biopestisida di Indonesia. Makalah pada Lokakarya Keanekaragaman Hayati untuk Perlindungan Tanaman, Yogyakarta, Tanggal 7 Agustus 2002.

Schmutterer H. 1995. The Neem Tree Azadirachta indica A. Juss. And Other Meliaceous Plants: Sources of Unique Natural Products for Integrated Pest Management, Medicine, Industry and Other Purposes. Weinheim: VCH.

Susanti, Lulus Dan Hasan Boesri. 2012. Toksisitas Biolarvasida Ekstrak Tembakau Dibandingkan Dengan Ekstrak Zodia Terhadap Jentik Vektor Demam Berdarah Dengue (Aedes Aegypti). Bul. Penelit. Kesehatan, Vol. 40, No. 2, Juni, 2012: 75 - 84

Suwahyono, U. 2010. Cara Membuat dan Petunjuk Penggunaan Pestisida nabati. Penebar Swadaya. Jakarta. 